\title{
La imagen de la Monarquía Hispana en la propaganda europea (s. XVI-XVII)
}

\author{
Laura Manzano Baena *
}

\begin{abstract}
RESUMEN ABSTRACT
Este articulo recoge las diferentes visiones de la imagen de la monarquía Hispana en los Países Bajos durante la llamada Guerra de los Ochenta Años. En tiempos de conflicto armado, el retrato de "España" y de los "españoles" no podía ser sino negativo, aspecto en el que coinciden los escritores más panfletarios y los más prestigiosos.

Todos los autores convienen en señalar los mismos defectos, que concuerdan en gran medida con la Leyenda Negra. Delinear los límites de esas críticas y su vinculación con las teorias políticas del momento es el principal objetivo de este trabajo.

This paper outlines different visions of the Hispanic Monarchy in the Low Countries during the Eighty Years War. In years of armed conflict, the portrait of "Spain" and the "Spaniards" could not be but negative, aspect repeated by the writers of pamphlets and the most celebrated ones. All the authors agree in the same faults, which match into a great extent with the Black Legend. The principal aim of this work is to sketch out the limits of these critics and its points in common with the political theories of the moment.
\end{abstract}

Analizar la imagen de "España" y de los «españoles» en el norte de Europa, especialmente en los Países Bajos durante los siglos $X V I$ y XVII no es tarea fácil. Peer Schmidt ha escrito un sugerente

* Universidad Autónoma de Madrid. 
ensayo ${ }^{1}$ sobre la visión que se tenía de Felipe II en el Imperio, pero después del Rey Prudente nos encontramos con un cierto vacio en la historiografía si se quiere ir más allá de las visiones distorsionadoras de la Leyenda Negra, término que, desde su fijación por Julián Juderías en 1914, ha sido el patrón desde el que se ha estudiado la visión exterior de la Monarquía Católica, tanto para reafirmarla como para intentar reformarla. Este punto de partida impide estudiar con la debida atención la evolución de la imagen de la Monarquía Hispánica tanto desde la óptica de sus antiguos súbditos como desde el Imperio, Inglaterra o Francia, porque la inexistente "España" no fue juzgada en los mismos términos desde el s. XVI ${ }^{2}$ hasta el s. XX.

Si bien es cierto que algunos argumentos se repiten con frecuencia a lo largo de los siglos (intolerancia religiosa, pueblo inculto, etc.), 10 cierto es que en torno a la crisis del 98 y el movimiento regeneracionista, momento en el que se gesta la obra de Juderías, a nadie se le ocurría emplear para atacar a España los argumentos de estar luchando por imponer un concepto de Monarquía Universal y un entendimiento confesional católico, encarnado por la Inquisición, y convertirla en símbolo del Imperio del Mal. La visión de España en los decenios anteriores a la Guerra Civil era muy diferente, especialmente en ciertos círculos, como reconoce $\mathrm{H}$. Henrichs, que afirma que tras la I Guerra Mundial, España fue para algunos el país europeo que más seriamente se implicaba en la lucha por los valores humanos y religiosos ${ }^{3}$. Es en torno al «desastre del 98», una vez España perdió los últimos restos de lo que fue su Imperio, cuando el punto de que parten las críticas cambia, ya no se ataca a España desde el exterior, sino que desde dentro del país se produce una reacción de análisis y estudio, desde una óptica a veces victimista, a veces lúcida, de España como problema y es ahí donde se inicia el estudio de las razones de la postergación de España en Europa y en el mundo del s. $x x$, iniciándose entonces la larga serie de estudios que han llevado a la creación del término «Leyenda Negra», punto obligado de referen-

Schmidt, P., La imagen de Felipe II en el Imperio Germano-Romano y en la historiografia alemana y austriaca, en Espacio, Tiempo y Forma, Serie IV. H. Moderna, t. 11, 1998, pp. $39 / 83$.

2 Arnoldsson remonta el origen de la Leyenda Negra al S. XIV. Arnolosson, S., La Leyenda Negra: estudios sobre sus origenes. Göteborg, 1960.

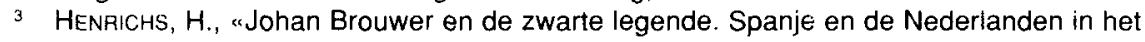
licht van de historiografie der "twee Spanjes",. Theoretische Geschiedenis, 11 (1984), p. 359. 
cia para cualquier estudio de la imagen de la Monarquía Católica durante la Edad Moderna.

Centrándonos en el estudio de la imagen de la Monarquía a lo largo de la llamada «Guerra de los Ochenta Años» observamos cómo durante esa época, mucho más limitada que los presuntos cinco siglos de críticas constantes a "España", la imagen de la Monarquía y de sus representantes no es la misma durante todo el periodo, sino que estuvo sometida a importantes alteraciones. Las críticas, pues se trata habitualmente de una visión negativa, son prácticamente las mismas durante los casi cien años que transcurren desde la entronización del hijo de Carlos $V$ hasta la firma de la Paz de Westfalia, pero los sujetos cambian, de los ataques a Felipe II y al Duque de Alba se pasa a los ataques a los generales de la Monarquía, respetando en gran medida a los sucesores del Prudente. La figura del Rey Católico se difumina, pero en su lugar militares y clérigos, sobre todo la Inquisición ${ }^{4}$, empiezan a ser el símbolo de esa España a la que hacen referencia los panfletos $u$ hojas volantes ${ }^{5}$. No obstante, no se puede obviar el hecho de que las imágenes de «España» estuvieron presentes en las Provincias Unidas durante los siglos XVI y XVII en todos los ambientes públicos, desde los puramente políticos, a los que se va a prestar más atención en el presente trabajo, hasta en los artísticos, desde la poesía hasta la pintura, pasando por el teatro ${ }^{6} \mathrm{y}$, naturalmente, por los púlpitos, ya que los pá-

4 Un interesante estudio sobre la imagen y fabulación en torno a la Inquisición en los $\mathrm{Pa}$ ises Bajos es THOMAS, W., "De mythe van de Spaanse inquisitie in de Nederlanden van de zestiende eeuw", Bijdragen en Mededelingen betreffende de Geschiedenis der Nederlanden, 105/3 (1990), pp. 325/353

5 Panfletos, pamfletten o Flugblätter son los términos con los que se denomina a la mayor parte de las obras impresas que tenían como función primordial informar, y persuadir al mismo tiempo en la mayoria de las ocasiones, al lector de hechos contemporáneos, especialmente durante los siglos $X \mathrm{VI}$ y $X \mathrm{VII}$, hasta que fueron perdiendo relevancia ante el avance de la prensa periódica, aunque continuaron teniendo importancia hasta bien entrado el Siglo de las Luces. Los panfletos no eran solamente la mejor y más rápida fuente de noticias, ni tan sólo hicieron que las demás formas de comunicación, orales y manuscritas, quedaran anticuadas.

6 Henk Duits señala la importancia de estos "medios de comunicación" a la hora de crear un estado de opinión concreto, comparándo su influencia con la que se ejercia desde los púlpitos. En un tiempo en el que se dependía tanto de la comunicación oral como en los s. XVI y XVII, el teatro tuvo una importante función en la conformación de la opinión pública. El teatro fue, desde esta óptica, un gran competidor de el otro medio de comunicación más poderoso, el púlpito. Duits, $H$., «De Vryheid, wiens waardy geen mensch te recht bevat'. 'Vrijheid' op het Nederlands toneel tussen 1570 en 1700 ", en Haitsma MuLIER, E.O.G. y Velema, W.R.E. (eds.), Vrijheid. Een geschiedenis van de vifftiende tot de twintigste eeuw. Amsterdam, 1999. pp. 99-131. Otras afirmaciones en esa misma dirección y que señalan la importancia de 
rrocos emplearon los sermones y los panfletos, pese a las teóricas restricciones, con gran frecuencia como vía de expresión de sus opiniones, incluso cuando éstas se oponían a las de las autoridades seculares ${ }^{7}$.

Así mismo se pretende aquí apuntar la importancia de la creación de imágenes antagónicas para la conformación de identidades nacionales, étnicas y religiosas, aplicándolo al surgimiento de los Países Bajos como nación y ver hasta qué punto el sentimiento de patria neerlandés fue producto de la guerra contra la Monarquía Católica y hasta qué punto la asunción de ciertos ideales, sobre todo la importancia del concepto de «libertad", se produjo como reacción contra los valores encarnados o adjudicados a la Monarquía Hispánica, sin olvidar la dificultad a la hora de definir el tipo de «libertad» al que se hacia referencia desde las Provincias Unidas, tanto por la pluralidad de matices que se le otorgaba al sustantivo en la época aquí estudiada como por la evolución de su significado a lo largo del tiempo ${ }^{8}$.

En los siglos que aquí nos ocupan, fueron muchos los que temieron la fuerza potencial de la palabra impresa, en tanto que solía ser considerada más veraz que los rumores o las comunicaciones orales, y además permanecía mucho más en el tiempo y tomaba la función de «memoria» 9;

la interacción de cultura escrita y oral lo encontramos en DavIS, N. Z., "Printing and the People", en su Society and Culture in Early modern France. Stanford, 1975, p. 208 o en KLAITS, J., Printed Propaganda under Louis XIV. Absolute Monarchy and Public Opinion. Princeton, 1976, pp. 5/6, el cual afirma que muchos años después de la invención de la imprenta las gentes alfabetizadas seguian cultivando hábitos de memoria y retórica oral derivados de tiempos anteriores. No obstante, el mundo visual fruto de la imprenta estaba influyendo al mismo tiempo incluso sobre la audiencia iletrada. En el $\mathrm{s}$. XVII se había configurado ya una extensa literatura popular impresa destinada a un público no alfabetizado.

7 Por la naturaleza de su oficio los párrocos consideraban que estaban en su derecho y que, además, era su deber expresar sus opiniones sobre la situación de la República .HARLINE, C. E., Pamphlets, Printing and Political Culture in the Early Dutch Republic. Dordrecht, 1987, p. 147.

8 Al hablar del tipo de libertad republicana, Hans W. Blom afirma que en el s. XVII se pueden rastrear en las Provincias Unidas diferentes antecedentes de Immanuel Kant, al mismo tiempo que se pueden reconocer ecos de Nicolás Maquiavelo, pero sin que esto nos permita hablar bajo ningún concepto de un 'Machiavellian Moment", o de un 'Reich der Freiheit'. En cierta manera la discusión en torno a la libertad en la República comparte elementos de ambos. BLOM, H. W., "Vrijheid in de natuurrechtelijke polietieke theorie in de zeventiendeeeuwse Republiek ", en HalT SMA MuLIer, E.O.G. y VELEMA, W.R.E. (eds.), Vrijheid. Een geschiedenis.... Amsterdam, 1999, p. 136.

9 KASTNER, R., Geistlicher Rauffhandel. Form und Funktion der illustrierten Flugblätter zum Reformationsjubiläum 1617 in ihrem historischen und publizistischen Kontext. Frankfurt a. M., 1982, p. 341. 
pese a que las tradiciones orales prevalecieron entre el pueblo llano, los autores de panfletos reconocían la influencia potencial de la imprenta. Los panfletos tenían su función: dar detalles sobre noticias y hechos y, como los sermones de los predicadores, introducir ideas y comentarlas.

En muchas ocasiones se dieron casos como el del teólogo arminiano Johannes Uitenbogaert. Autor de setenta y ocho obras de carácter polémico, lo que lo convierte en uno de los más prolíficos panfletistas conocidos, fue al mismo tiempo uno de los mayores oponentes de los libelos, pero sus alegatos impresos contribuían a crear polémica y, como consecuencia, un mayor número de publicaciones. Esta actitud fue compartida por el propio gobierno, que pretendió contrarrestar la avalancha de panfletos criticando la política del mismo mediante la producción y promoción de pasquines que apoyasen su línea de actuación, con lo que potenciaban el papel de las hojas volantes en la conformación de corrientes de opinión ${ }^{10}$.

Aunque la mayoría de las obras que aparecen reseñadas en este estudio pertenezcan claramente a la literatura panfletaria, con todas sus connotaciones, no todas las hojas tenían intención polémica, sino que también reflejaban una temática moral-religiosa, o simplemente recogian los lamentos populares ante desgracias naturales, entre otros temas ${ }^{11}$.

Los principales catálogos de estas hojas ilustradas son, en el caso del Imperio, los debidos a W. Harms, Illustrierte Flugblätter aus den

10 Las quejas en torno al exceso de publicaciones no fueron exclusivas de las Provincias Unidas, en el caso de la Francia del s. XVII también se criticaba desde panfletos y desde el gobierno el hecho de que cada año se publicase un mayor número de estas obras, siempre considerándolas desde una óptica negativa. Sawyer, J. K., Printed Poison. Pamphlet Propa ganda, Faction Politics, and the Public Sphere in Early Seventeenth-Century France. Berkeley, Los Ángeles, 1990, p. 17.

11 En ningún caso se las puede considerar armas especialmente encaminadas a la creación de un estado de opinión contrario a la Monarquia Católica; en los dos primeros volúmenes del catálogo neerlandés más ambicioso de todo tipo de panfletos y hojas volantes y que abarcan los años que aquí nos interesan, el Catalogus van de pamphletten-verzameling berustende in de Koniklijke Bibliotheek, 's Gravenhage, 1889-1920, elaborado por W.P.C. Knuttel, menos de una décima parte de los impresos alli consignados hacen referencia a "España", y de ese escaso diez por ciento, menos de la mitad son críticas directas a la Monarquía Católica. Durante el periodo 1607-1648 «España» estuvo presente como tema en el $44,5 \%$ de los panfletos, lo que no significa que fuese el sujeto principal de aquellos en los que se mencionaba. No obstante, entre aquellos pasquines que alcanzaron mayor difusión durante la segunda mitad de la Guerra de los Ochenta Años, los que se pueden considerar bestsellers, "España" si que fue el sujeto principal. HARLINE, C. E., op. cit., p. 38-39. 
Jahrhunderten der Reformation und der Glaubenskämpfe, Coburg, 1983 y Deutsche Illustrierte Flugblätter des 16. und 17. Jahrhunderts, Tübingen, 1985 y a J. R. Paas, The German Political Broadsheet, 1600-1700, Wiesbaden, 1985-1986; para los Países Bajos resulta imprescindible el ya mencionado de Knuttel, así como los trabajos de P. A. M. Geurts, De Nederlandse opstand in de pampletten, 1566-1584, Nijmegen, 1956, y C. E. Harline, Pamphlets, printing, and political culture in the early Dutch Republic, Dordrecht, 1987; para Francia se cuenta, entre otras, con las compilaciones de D. V. Welsh, $A$ checklist of French political pamphlets, 1560-1644 in the Newberry Library, Chicago, 1950 y A second checklist of French political pamphlets, 15601653 in the Newberry Library, Chicago, 1955 y de R. O. Lindsay y J. Neu, French Political Pamphlets, 1547-1648: a Catalog of major collections in American libraries, Madison, $1969^{12}$.

Antes de analizar la imagen de España en el exterior resulta necesario delimitar los límites espaciales de la misma. Si por una parte parece posible que el término «España» actuase de fuera a dentro, lo cierto es que era empleado con frecuencia en el interior durante el s. XVII ${ }^{13}$. Ahora bien, si parece claro que el término España era un punto de referencia para los hombres de la época, resulta curioso que se tenga conciencia desde el s. XV en el interior de la Península lbérica de una pluralidad de Españas (Hispaniae) ${ }^{14}$ mientras que desde fuera la definición que merecen castellanos, catalanes, valencianos, aragoneses e incluso napolitanos y portugueses en ocasiones sea la de «españoles» ${ }^{15}$.

12 Ninguno de los catálogos es completo, el más amplio es el de Knuttel. Sobre el problema de la realización de catálogos de este tipo de fuentes ver PEGG, M. A., "Short Title Catalogues. Notes on Identity of Texts", en KÖHLER, H.J. (ed.), Flugschriften als Massenmedium der Reformationszeit. Beiträge zum Tübinger Symposion 1980. Stuttgart, 1981, pp. $29 / 41$.

13 En este sentido habla Matías de Novoa, cronista de Felipe IV, pues considera que en 1640 se inician las "guerras de España", en contraposición a las guerras europeas sostenidas hasta entonces desde el tiempo de los Reyes Católicos. Jover Zamora, J. M. y LOPEZCordón, M. a V., "La imagen de Europa y el pensamiento político-internacional», en Historia de la cultura española. Historia de España Menéndez Pidal, tomo XXVI, p. 623.

14 Fernández Albaladejo, P., "España desde España», (p. 63-75), en Arrieta Alberdi, J., Bel.enguer Cebrià, E. y Fernandez Albaladejo, P., Idea de España en la Edad Moderna. Valencia, 1998, PP. 63/75 y TATE, R., Ensayos sobre la historiografía peninsular del s. XV. Madrid, 1970 , p. 123 y ss.

15 Esto contrasta con las afirmaciones de Pau Claris, líder de la revuelta catalana, que en sú discurso de 10 de septiembre de 1640, diferencia entre Castilla y España; los catalanes sublevados se consideran enemigos de la primera pero parte de esta última. Cit. en Jover ZAMORA, J. M. y LOPEZ-CORDÓN, M. ${ }^{a}$ V; op. cit., p. 473. 
La indefinición de "España» se refleja en la hoja ilustrada Gross Europisch Kriegs-Balet/ getantzet durch die Könige und Potentate/ Fürsten und Republicken/ auff dem Saal der betrübten Christenheit. (tras $1645)^{16}$, que presenta a todos los monarcas, príncipes, etc. de Europa, bien como espectadores o como actores de un baile que se desarrolla en la Cristiandad. Ahí se presenta al "Rey de Castilla" de la mano del Emperador, mientras que con la mano libre va dejando caer dinero de su bolsa por el suelo que, no olvidemos, representa las tierras de la Europa desolada. Se hace así referencia al papel de la Monarquía Hispana como sustentadora económica del bando católico ${ }^{17}$. En el texto que acompaña a la imagen se menciona, en tono neutro, la sublevación portuguesa y la entronización del Duque de Braganza en 1640.

El grabado nos indica de que el rey de España lo era de Castilla, pero los demás territorios, desde el exterior, no se incluian tan automáticamente en esa ecuación; esto explica que Aragón pudiera ser un hito mítico de la defensa de las libertades con la divisa pro lege et grege mientras que los Habsburgo, sobre todo los españoles, eran el símbolo de la tiranía y la falta de libertades, imagen que, aunque no corresponda con la presencia de elementos comunes de gobierno de toda la Vieja Europa, heredarán los Borbones en el interior ${ }^{18}$.

Al intentar crear un ente político que abarcase la pluralidad de territorios de la Monarquía se llegó a una solución radicalmente distinta de la alcanzada en el Imperio, donde la lengua se convirtió en el nexo de unión ${ }^{19}$. En la Monarquía Hispana es la catolicidad, respaldada

16 HaRMS, W., Illustrierte Flugblätter aus den Jahrhunderten der Reformation und der Glaubenskämpfe. Coburg, 1983, pp. 206-207.

17 El papel de la Monarquía Hispana en la financiación de los conflictos aparece también en la Declaración del Rey de Francia sobre el rompimiento de la guerra contra el Rey de España (1635), BNM, Ms. 10713, ff. 208-217, en la que se acusa a los españoles de haber estado repartiendo "dineros, dados a todos aquelios que an podido [...] armar contra nuestros aliados", f. 210r-210v.

18 Barudio, G., Der Teutsche Krieg, 1618-1648. Frankfurt a. Main, 1985, p. 40. Un claro ejemplo de la imposibilidad de adscribir automáticamente los mismos rasgos a aragoneses y a castellanos en los siglos XVI y XVII lo encontramos en las obras de Antonio Pérez, el cual señala la animadversión que se sentía hacia los castellanos en el seno de la Monarquía. Pérez, Antonio, Relaciones y cartas (vol. 1), Alvar Ezouerra, A. (introd., notas y edición), Madrid, 1986.

19 Quintana, A. (introd., selección, traducción y notas), Poesía Alemana del Barroco. Barcelona, 1981, p. 19. Para el papel de la imprenta en la creación de círculos lingüisticos de alcance superior a los principados vid. HARTWEG, F., "Buchdruck und Druckersprachen der frühneuhochdeutschen Periode», en KöHLER, H.J. (ed.), Flugschriften als Massenmedium. Stuttgart, 1981, pp. 43/64.. 
por un título dado por el pontífice, lo que se convierte en el nexo de unión de los diversos territorios. La defensa de la religión verdadera irá entonces pareja al proceso de fortalecimiento del poder monárqui$c o$, que convertirá la herejía en rebelión y los rebeldes en herejes ${ }^{20}$, además de convertirse en la principal fuente de ataques contra la Monarquía, al identificarla con el catolicismo contrarreformista más agresivo ${ }^{21}$. Ejemplo de esto es Prognosticon. Oder practica auff das..., fechado en torno a 1585-86, en la que, además de atacar a la Orden de Loyola, se critica a los caballeros de la Orden del Toisón de Oro. En este grabado también se lanzan ataques directos y exclusivos a la Monarquía Hispana, como es que por defender sus intereses en Francia y en los Países Bajos, no reparen en la cantidad de sangre cristiana derramada ${ }^{22}$.

Además de criticar su papel como malos consejeros del Emperador, especialmente de Fernando II, a los miembros de la Compañía de Jesús también se les culpabilizaba de todo enfrentamiento confesional en el Imperio, como muestra, entre otros, el panfleto Discurs von dem jetzigen Zustand in Böhmen, 1618 o Was ist das für ein setzam Bildt..., $1619^{23}$, recibiendo así ataques similares a los hechos a la Monarquía Católica, a la que franceses, súbditos protestantes del Imperio y rebeldes bohemios acusaron siempre de ser la instigadora y apoyo financiero de sus enemigos, como se ha visto en el panfleto Gross Europeisch

20 BCuzA, F., «De política y tipografía. En torno a Felipe II y los Países Bajos», Imagen y propaganda. Capítulos de historia cultural del reinado de Felipe II. Madrid, 1998, p. 155. Esta identificación se intentó refutar desde aquellos súbditos que profesaban una religión diferente a la de su señor. Un ejemplo lo encontramos en Vertoog ende Openinghe om een goede, salighe ende generale vrede te maken in dese Nederlanden, ende deselven onder de ghehoorsaemheyt des Conincx, in haere oude voorspoedicheyt, fleur ende welvaert te breng. hen. By maniere van supplicatie, opúsculo escrito en torno a mayo de 1576 en el que se afirma lo erróneo de forzar al prójimo para que acepte una religión en la que éste no cree, ya sea por voluntad del Rey o del Papa. Gelderen, M. van (ed.), The Dutch Revolt. Cambridge, 1993 , p. 119.

21 PowelL, P. W., Árbol de odio. Madrid, 1972, p. 98. No obstante existen panfletos en los que se ataca a la Contrarreforma sin que se mencione a la Monarquía Católica, como Der Sih dich für, (1632) o Vergleichung. Des Babst Schlüssel mit des Apostels Petri Schlissel so wol auch deren Personen, fechado a mediados del s. XVII. HaRms, W., (ed.), Illustrierte Flugblätter... pp. 10-11 y $82-83$.

${ }_{22}$ Harms, W., (ed.), Die Sammlung der Hessischen Landes und Hochschulbibliothek Darmstadt, t. IV de Deutsche Illustrierte Flugblätter des 16. und 17. Jahrhunderts.Tübingen, 1987, p.90-91.

23 PaAS, J.R., The German Political Broadsheet 1600-1700. Wiesbaden, 1985, vol.2, pp. 157 y 194. 
Kriegs-Balet..., en la Declaración del rey de Francia...y que también se ve en Böhmischer Unruh Schauspiegel..., $161{ }^{24}$.

También desde Inglaterra se identificaron con frecuencia, y siempre para mal Monarquía Católica y agentes de la Contrarreforma. Esto se puede observar en Deo trin-uni Britanniæe bis ultori... (Samuel Ward, Ámsterdam, 1621) ${ }^{25}$, que alerta contra la posible unión de Inglaterra con la Monarquía Hispana fruto del matrimonio del futuro Carlos I con la Infanta María, recordando la Armada de 1588 y la «Conspiración de la Pólvora" de Guy Fawkes (5 de noviembre de 1605) como ejemplos de la animadversión de los hispanos respecto a Inglaterra ${ }^{26}$. También se los presenta de nuevo como traicioneros y falsos, en un momento en que en la literatura panfletaria inglesa el Papa y el Monarca hispano solían ser mencionados juntos, equiparándose el catolicismo y «España», con lo que se proyectaban hacia la Monarquía Católica los sentimientos de animadversión que despertaban los católicos ingleses ${ }^{27}$.

La supeditación de la defensa de la religión católica a los intereses políticos y estratégicos es otra de las acusaciones habituales hechas por los enemigos de la Monarquía Católica. Así, dentro de la transformación del "español» en un compendio de defectos y su conversión en un arquetipo fuertemente negativo, hasta la religiosidad se convierte en motivo de crítica, pues se afirma que se trata de un alarde hacia

24 ibid., p. 195

25 íbid., p. 342-343.

26 No obstante, en algunos panfletos denostando el intento de voladura del parlamento producidos poco después de tener lugar los hechos no se menciona la posible implicación de la Monarquía Católica, como muestran Consilium Septem Nobilium Anglorum conivranti in necem lacobi I Magnae Britanniae Regis.., 1605 (escrito en lengua inglesa), Anschlag siben Engellender vom Adel.., Christoff Mang. Ausburgo, 1605 (edición bilingüe latín-alemán) y Kurzer und eigentlicher historischer bericht/ wie und welcher..., 1606 (edición bilingüe latinalemán), todos recopilados en PAAS, J.R., op. cit., vol.1, pp.184-187.

27 MaLtBy, W. S., The Black Legend in England. The development of anti-Spanish sentiment, 15558-1660. Durham, 1971, p. 29. Existen sin embargo hojas ilustradas como The Lambe speaketh. Why do you crucifie me..., fechado en torno a 1554 , en el que se hace referencia a la recatolización emprendida por María Tudor tras su ascensión al trono de Inglaterra, criticando a los ministros de la reina, no a ella o a su esposo. HaRms, W., (ed.), Die Sammlung der Herzog August Bibliothek in Wolfenbüttel..., t.l-II de Deutsche IIIustrierte Flugblätter des 16. und 17. Jahrhunderts. Munich, 1980, pp. 16-17. No obstante, la razón más socorrida para atacar a la Monarquía Hispana fue siempre la confesión. KAMEN, H., "La visión de España en la Inglaterra isabelina», en KAMEN, H. y PEREZ, J., La Imagen internacional de Felipe II: "Leyenda negra" o conflicto de intereses. Valladolid, 1980 , p. 49. 
el exterior pero sin correspondencia hacia el interior ${ }^{28}$. Esto se relaciona con la identificación de la Monarquía Hispánica con los turcos, a los que Ferrier considera iguales en crueldad ${ }^{29}$. Por otra parte, se afirmaba que los dos pueblos eran incapaces de dominar sus afanes de dominio universal y se trazaban paralelismos sobre su origen, proyectándose las características achacadas a los turcos sobre los hispanos, considerándoles avariciosos, perversos, idólatras y desleales ${ }^{30}$.

No eran los turcos los únicos infieles con los que se relacionaba a los hispanos. Martín Opitz, el principal poeta del s. XVII alemán, escribió en 1620 una Oración para que Dios eche a los españoles del Rin ${ }^{31}$, con motivo de la amenaza de Spínola sobre el Palatinado en septiembre de 1620, llamándoles "marranos", en referencia al origen judío de las tropas hispanas, y bárbaros.

Los argumentos empleados en las diatribas hechas contra España desde Francia en el siglo XVI inciden básicamente en aspectos políticos y religiosos, aunque en este caso no condicionados por las diferencias confesionales. Se criticaban la avaricia y usurpación de los reyes españoles; se denunciaba de la situación de miseria de Castilla y la opresión a la que los castellanos sometían a los pueblos bajo su gobierno; se atacaba la violencia religiosa de la Inquisición y a los jesuitas y se enumeraban los defectos antropológicos de los españoles (pereza, insolencia, fanfarronería, etc.) ${ }^{32}$ Durante el s. XVII los motivos de las invectivas fueron muy similares ${ }^{33} y$ era evidente la inquietud ante

28 Un ejemplo de esto es $A$ Defence and True Declaration of the things lately done in the lowe Countrey whereby may easily be seen to whom all the beginning and cause of the late troubles and calamities is to be imputed, editado en Londres en $1571 \mathrm{y}$ basado en el original latino publicado el año anterior, donde se asevera que los miembros de la Corte de Felipe II, en su trato diario con el monarca, escondian su crueldad y su insaciable ambición bajo el velo de la más piadosa de las religiosidades. Gelderen, M. van (ed.), The Dutch Revolt, p. 15.

${ }^{29}$ Le Catholique d'Estat, ou Discours politique des alliances du Roi tres Chrestien contre les calomnies des ennemis de son Estat. Par le sieur DU FERRIER. Precedido de una dedicatoria a Luis XIII, en Recueil de diverses pièces pour servir à l'Histoire, s.I., 1635, p. 136.

sо Thomas, W., "1492-1992: heropleving van de 'Zwarte Legende'?", Onze Alma Mater, XLIV (1992), p. 408.

31 QuintanA, A.,op. cit., p. 121-123.

32 García CÁrcel, R., La leyenda negra. Historia y opinión. Madrid, 1992, p. 49-50.

33 Estas acusaciones también están presentes en los panfletos protestantes, especialmente al hacer referencia al poder del Santo Oficio. Los exiliado españoles como Francisco de Enzinas y Reginaldus Gonsalvius Montanus describieron en sus influyentes escritos la crueidad de la Inquisición hispana. Resaltaron el, a su juicio, excesivo poder de los inquisidores y su argumentación consistía en resaltar que, además, su principal interés no era la re- 
las ideas defendiendo el tiranicidio de Mariana y Suárez por las resonancias que pudieran tener en la configuración del pensamiento hugonote. Un elemento propio en la disputa entre polemistas franceses e hispanos es la discusión en torno a la conveniencia de las alianzas con herejes, ya que ambos bandos intentaban denostar las del enemigo y justificar las propias.

Pese a que a partir de la década de los treinta del s. XVII se empezaron a producir numerosos llamamientos en pro de la paz, se siguieron editando grabados como Spanische Kranckheitt (1632), ${ }^{34}$ en el que se retrata la enfermedad del "Señor español" como consecuencia de su desmedida ambición y se le caracteriza con los siguientes epítetos: Tyrannis, Superbia, Avaritia, Perfidia, Parricidium, Fraticidium, Crudelitas, perjurium, etc., epítetos que se hacían extensivos a todo el "partido español», en el que se incluía a los príncipes católicos del Imperio.

Vinculadas a las acusaciones de falsa religiosidad se encuentran las relativas a la tiranía hispana. En la Verantwoordinge, verklaringhe ende waerschouwinghe des Princen van Oraengien (Advertencia del príncipe de Orange...) de 1 de septiembre de 1568, escrita desde su exilio en Alemania, éste afirmaba que tras la integración de los Países Bajos en la Monarquía Católica algunos grandes de España habian intentado obtener el poder de gobernar y tiranizar los prósperos Países Bajos como hacían en todos los demás territorios bajo su dominio ${ }^{35}$. Esto lleva a un nuevo rasgo distintivo de España, descrito así como pais sin libertades, lo que implica que desde fuera se extienden los rasgos propios de Castilla, exagerados, al conjunto de territorios que se querían considerar «España», aunque chocase con la defensa que hacian los territorios de sus libertades. No obstante, en alguna ocasión, la literatura polémica reconoció el interés de los aragoneses por preservar la antigua constitución. Así, en A Defence and True Declaration..., obra producida en el entorno de Guillermo de Orange, se les

ligión sino el poder. Pollmann, J., «Eine natürliche Feindschaft: Ursprung und Funktion der schwarzen Legende über Spanien in den Niederlanden, 1560-1581 «, en BosBaCH, F. (ed.), Feindbilder. Die Darstellung des Gegners in der politischen Publizistik des Mittelalters und der Neuzeit. Köln, Weimar, Wien, 1992, p. 76.

34 HaRms, W. (ed.), Die Sammiung der Herzog August Bibliothek in Wolfenbüttel..., t. II, Munich, 1980, p. 510-511.

35 Kossmann, E.H. y Mellink, A.F. (eds.), Texts concerning the Revolt of the Netherlands. Cambridge, 1974, p. 84. (la traducción es mía). 
consideraba la principal provincia de España en libertades, en nobleza y en amplitud de dominios, para contrastar así con la tiranía que instauró en esa Corona la Inquisición ${ }^{36}$.

España se convirtió así en un referente negativo que se utilizaba para criticar a la rama hispana de la casa de Habsburgo. A sus monarcas se les llamaba reyes de España en contraposición a Carlos V, que aparecía como figura un tanto idealizada hasta por los protestantes alemanes ${ }^{37}$. Este recuerdo embellecido explica la presencia del Emperador en los panfletos conmemorativos del centenario de la confesión de Augsburgo, la primera gran celebración festiva de la Confesión. En las muchas Flugblätter surgidas al calor de este jubileo podemos observar que la figura de Carlos $V$ no mereció el rechazo por parte de los protestantes que sí recibieron sus descendientes ${ }^{38}$. Esto indica que la figura de Carlos $V$ mereció un tratamiento muy diferente desde el Imperio que sus descendientes, por más que P. Schmidt afirme que Felipe II iba a ser el heredero de la imagen fuertemente negativa que de los españoles ya se había formado durante la vida de su padre ${ }^{39}$. Son varias la fuentes que nos previenen del riesgo de asignar alegremente a Carlos $V$ los rasgos mediante los que se caracteriza a su hijo ${ }^{40}$. En el caso específico de los Países Bajos, hay que señalar la

36 Gelderen, M. van, The Dutch Revolt, p. 17.

37 Esta idealización de Carlos $V$ parece que acontece a partir de la segunda mitad del $s$. xvı, porque durante la guerra contra la Liga de Smalkalda parece ser que se le representó como enemigo de los teutschen y enviado de Satán. PowELL, P. W., op. cit., p. 69. En este contexto temporal se articulan, en oposición al Emperador, las teorías del derecho de resistencia, principalmente desde el bando luterano. SkINNER, Q., The foundations of modern political thought (2-The age of Reformation). Cambridge, 1978, p. 189-206. No obstante, se produjo en este caso, una oposición a la autoridad a través de los ejecutores de sus mandatos porque asi se retomaba un argumento ya tradicional para protegerse de las inculpaciones de ruptura de obediencia al príncipe. No era contra él contra el que se luchaba, sino contra los malos consejeros, resaltándose especialmente cuando los «malos consejeros" no eran naturales del territorio. PollmanN, J., op. cit., p. 78.

38 De Heiligen Römischen Reichs Hoheit/ Welche zu betrachten Anlass gegeben... (Matthäus Krüger, 1630) y Abbildung, welcher Gestalt vor dem Grossmächtigsten Keyser Carln dem $V$ umif Reichstag zu Augspurgk... (Johann Dürr, Dresde, 1630) se refleja claramente esta visión positiva. Harms, W., (ed.), Die Sammlung der Herzog August Bibliothek in Wolfenbüttel..., t. II, Munich, 1980, p. 374-375, 378-379.

39 SchmidT, P., op. cit., p. 41.

40 Por una parte tenemos el Acta de Abjuración de las Provincias Unidas o Plakkaat van Verlatinge, fechada e! 26 de julio de 1581, en donde se hace referencia a Felipe II como "Rey de España", distinguiéndolo del emperador Carlos V, del que se dice que era recordado con respeto por sus antiguos súbditos y al que las Provincias habían prestado importantes servicios, igual que a su hijo y heredero, y, por otra, tenemos las palabras de Markus Welser, 
importancia que en los panfletos iban adquiriendo las referencias pseudo-históricas como argumento de autoridad. Los autores de los panfletos crearon mitos históricos, invisitiendo a personajes del pasado de todo tipo de virtudes, algo que muy notable en el caso de Carlos $V$, retratado como el buen gobernante, nativo del territorio y resptuoso de los privilegios de las Provincias, aunque la práctica política de Felipe II continuara en general los diseños teóricos de su padre.

Ante el aluvión de críticas de procedencias múltiples, me gustaría señalar brevemente los intentos de defensa de la Monarquía Hispana ante los ataques. En contra de la idea de Peer Schmidt de que la Monarquía Hispana no produjo obras de propaganda de difusión masiva se encuentran las aportaciones de F. Bouza. Éste afirma que en torno a la Armada de 1588 y a la candidatura de la infanta Isabel Clara Eugenia al trono francés, la imprenta fue empleada a gran escala, no sólo en el interior de la Monarquía sino a escala internacional ${ }^{41}$, campaña centrada siempre en defender la catolicidad de la Monarquía Católica y su papel como Defensor de la $\mathrm{Fe}$ en un momento en el que los alemanes tuvieron que reconocer la potencia mundial era España, y que la reivindicación alemana de constituir un imperio había llegado a ser -salvo en el aspecto escatológico y de la tradición jurídica- sumamente cuestionable ${ }^{42}$. A través de la propaganda. Felipe II pretendía legitimar la existencia de un imperio propio, merecedor de mayor grandeza al no albergar herejes en su seno.

Aunque menos estudiada y nunca tan efectiva como la que llevaban adelante sus antiguos vasallos, Felipe II intentó justificar su actividad en defensa de la religión católica y reafirmar lo legítimo de su autoridad 43 . Esto nos explica el interés del monarca por las ediciones de Plantino,

un burgués y erudito de Augsburgo que en una carta afirma "Caroli et Francisci exempli caussa historiam, qui non aliter Gallus aliter Germanus narret" (Toma la historia de Carlos V y Francisco I, un alemán y un francés la contarian siempre de manera distinta), lo que nos indica que consideraba que Carlos era alemán, al menos desde el punto de vistas de los súbditos del Imperio. Kossmann, E.H. y Mellink, A.F. (eds.), op. cit., p. 217 y Markus Welser a De Thou, 23 octubre 1604, B.N., Paris, MS Dupuy 632, fol. 74 r.; cit. en Grafton, A., The Footnote. A curious history. London, 1997, p. 139.

a1 BOUzA, F., "Monarquía en letras de molde._Tipografía y propaganda en tiempos de Felipe Il", en su Imagen y propaganda. Capítulos de historia cultural del reinado de Felipe II. Madrid, 1998, p. 136.

42 SCHMIDT, P., op. cit., p. 56.

43 BouzA, F., De política y tipografía..., p. 156. 
al que se perdonaron sus veleidades calvinistas en tanto que colaborara con el Rey Católico en sus estrategias editoriales ${ }^{44}$. Plantino es un ejemplo de impresor que separaba sus ideas religiosas y sus convicciones políticas de los textos que se imprimian en sus talleres, sin que esa tibieza o falta de adscripción clara le impidiese aparecer sucesivamente, entre 1580 y 1585, como «Impresor del Rey», "de los Estados Generales", "del Duque» y de nuevo como "Impresor del Rey». ${ }^{45}$

Además resulta necesario recordar que la Monarquía Católica en particular contaban con medios de difusión vetados a los protestantes, en especial a los calvinistas, como era la iconografía religiosa presente en los altares de las iglesias. Los fieles, al acudir al servicio religioso, eran adoctrinados a través de imágenes similares en esencia a las de las Flugblätter ${ }^{46}$. No obstante, la propaganda hispana carece habitualmente de la riqueza expresiva de los panfletos ${ }^{47}$. Para explicar esto es

44 VOET, L., Felipe II, Guillermo de Orange y el tipógrafo Christopher Plantino. Los dos principales protagonistas del drama holandés del s. xvI, vistos a través de la azarosa vida de un humilde ciudadano, en Alvar Ezquerra, A. (coord.), Imágenes históricas de Felipe II, Madrid, 2000, pp. 43/58. Pese a las acusaciones realizadas habitualmente a Felipe II y a sus sucesores de haberse dejado llevar en todo momento por la "intolerancia", el monarca católico dio aquí prueba de un gran pragmatismo. El caso de Plantino, estudiado profusamente por Voet, es también ejemplo de impresor de la época, si bien ningún otro impresor alcanzó su capacidad editorial.

45 El argumento exculpatorio era la necesidad económica, lo que concuerda con las afirmaciones al respecto de Harline, que señala que era un argumento primordial hasta para los impresores más concienciados ideológica o confesionalmente. HARLINE, C. E., op. cit., p. 91. En la misma dirección se expresa ARndt, J., Das Heilige Römische Reich und die Niederlande 1566 bis 1648. Politisch-konfesionelle Verflechtung und Publizistik im Achzigjährigen Krieg. Colonia, 1998, p. 235.

46 Un magnífico ejemplo de este tipo de representaciones es el cuadro de Giovanni Pietro de Pomis, fechado en 1616, "El Archiduque Fernando emplazado por la Religión para acometer la restauración del catolicismo" y que se encuentra en el altar mayor de la Antoniuskirche de Graz. Otras formas de comunicación propagandística de la que se servía la Monarquía Católica eran aquellas que se expresaban a través del ceremonial. KASTNER, R., op. cit., p. 120. Una sugerente aproximación al uso de las procesiones religiosas como medio de

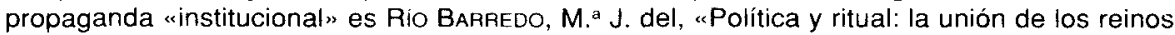
en el Corpus madrileño de la década de 1640", Memoria y Civilización 3, 2000, pp. 73/106.

47 Pese a todo, algunos panfletos neerlarideses consideraban que una importante cantidad de los pasquines publicados en las Provincias Unidas y que contradecian la acción de los regentes estaban financiados por la Monarquia Católica, como Vereenighde Nederlanschen Raedt, het eerste Deel. Bewijsende met klare Exempelen ende levendige redenen, datmen dese Vereenighde Nederlanden (met Godes hulpe) in korten tijd, van de vreese en perijckelen der tegenwoordige Oorloge kan verlossen, mitsgaders den Staedt haerder Bondgenoten, redresseren ende verseeckeren's Gravenhage, 1628, Kn. 3797, uno de los panfletos más largos aqui reseñados y que conoció numerosas reediciones y reimpresiones. 
necesario tener en cuenta que, en aquellos lugares bajo la influencia del monarca, éste era siempre alabado en los discursos públicos. El rey, hasta para aquellos que se oponían a su política, resultaba siempre una figura ensalzada, si no él personalmente, al menos sí la dignidad que representaba y el denigrarlo públicamente era un delito que muy pocos estaban dispuestos a cometer. La mayoría de los neerlandeses, incluyendo a algunos calvinistas detentadores de oficios públicos, dudaron antes de jurar solemnemente el Acta de Abjuración de 1581. Esto no hace sino mostrar lo fuerte que era el respeto a la autoridad legítima ${ }^{48}$. El único momento en lo que esto podia tener lugar era en los tan temidos periodos de minoridad, ya que la presencia de un rey niño y una regencia era siempre un elemento desestabilizador ${ }^{49}$.

La necesidad de mantenerse en la medida de los posible dentro de ciertos límites de reconocimiento a la soberanía regia se ve confirmada por la actitud del propio príncipe de Orange en la primavera de 1568, cuando, en una carta dirigida a Guillermo de Hesse mostraba sus dudas en torno a la política publicística a seguir y consideraba menos arriesgado atacar al Duque de Alba que al gobierno hispano en general, esperando así no levantar las iras del rey y sin plantearse dirigir los ataques directamente contra el monarca ${ }^{50}$.

El carácter sacro de la dignidad monárquica es lo que subyace en la negativa a dirigir los ataques contra el rey y lo que explica que, salvo en casos muy excepcionales, como durante la Guerra de los Ochenta Años o en la Inglaterra de Carlos II, las figuras denostadas en las revueltas fueran los malos ministros ${ }^{51}$. La figura real se sitúa en cierta manera por encima del bien y del mal, hasta sus actos tiránicos pueden llegar a ser justificados y, hasta que se desarrollaron las teorías de la resistencia, no disculpaban el forma alguna la revuelta contra la autoridad regia ${ }^{52}$.

48 Harline, C. E., op. cit, p. 173

49 SAWYER, J.K. op. cit, P. 2.

50 Guillermo de Orange a Guillermo de Hesse, 17-4-1568, en Archives ou Correspon dance inédite de la maison d'Orange-Nassau, Prinsterer, G. van (ed.), Serie (reihe) 1, t. 3 , Leiden, 1836, p. 210.

51 Al referirse a la dimensión sagrada de la institución monarquía resulta imprescindible hacer referencia a $\mathrm{BLOCH}, \mathrm{M}$., Les Rois Thaumaturges. Étude sur le caractère surnaturel attribué a la puissance royale particulièrement en France et en Angleterre. Estrasburgo, 1924 y KANTORowicz, E. H., The King's two Bodies. A Study in Mediaeval Political Theology. Princeton, 1957.

52 Era muy habitual la opinión de que las injusticias realizadas por el rey no liberaba a sus súbditos de su obligación de obediencia, basándose en dos argumentos, uno teórico, 
Una vez estalló la Guerra de los Treinta Años, pasquines y grabados no mencionan apenas personalmente a Felipe II. En la mayoría de los casos sólo se habla del rey español. Fue precisamente en los años en que el conflicto germánico estuvo más marcado por consideraciones confesionales, en el período que transcurrió entre 1619 y 1621 , cuando, tanto por la cantidad como por la variedad y calidad de las publicaciones, las críticas a la Monarquía Católica más centradas en los argumentos típicos de la Leyenda Negra alcanzaron su máximo apogeo en el Imperio ${ }^{53}$. Sin embargo, dentro de ese mismo período bélico, Jover señala 1635 como el año culminante dentro de ese proceso ${ }^{54}$, poniendo así el acento en la entrada de Francia en la guerra y no en las consecuencias de la fase bohemio-palatina.

Esto nos remite a un problema habitual en la interpretación de los conflictos de la Monarquía Hispánica; si la mayor parte de los combatientes, incluido el Emperador, fueron dejando en cierta medida de lado los aspectos confesionales más agresivos a medida que transcurría la Guerra de los Treinta Años, para la Monarquía Católica la lucha, incluso cuando Francia entró en la guerra, siempre implicó la defensa de la verdadera catolicidad, siguiendo con los esquemas de la Paz Austriaca.

Una fuerte influencia en la formación de la imagen de Felipe II fuera de los límites de la Monarquía Católica la tuvo la rebelión de los Países Bajos, por la influencia directa en la zona de Westfalia, desde donde impregnaron la idea que desde el Imperio se tenía de la Monarquía Hispana, como por la importancia de la publicística neerlandesa. Ésta desarrolló y popularizó las imágenes negativas formadas anteriormente, incorporando también las visiones desfavorables que se estaban formando en el seno del partido hugonote francés durante los primeros años de la Revuelta, como muestra el hecho de que la Apología de Guillermo de Orange fuera escrita por un hugonote francés, Pierre Loy-

basado en el Cristianismo, y otro de índole práctica, pues se consideraba que toda revuelta llevaría a desórdenes más duros que la tiranía regia. Además, el gobierno fruto de la desobediencia a la autoridad establecida por Dios siempre sería peor que cualquier opresión que ésta pudiera ejercer. KossmanN, E. H., "Over de koning die geen kwaad kan doen", en su Polietieke theorie en Geschiedenis. Verspreide opstellen en voordrachten. Ámsterdam. 1987, p. 119.

53 SCHMIDT, P., op. cit., p. 67.

54 JOVER ZAMORA, J. M., 1635. Historia de una polémica y semblanza de una generación. Madrid, 1949, p. 35. 
seleur de Villiers ${ }^{55}$. Además es necesario tener en cuenta que los exiliados eran en la práctica totalidad calvinistas, algo de gran trascendencia al ser los seguidores de Calvino mucho más radicales que los luteranos en su crítica de la Iglesia católica y del papado ${ }^{56}$.

La forma habitual de expresión de los ataques fueron los panfletos, que formaban parte importante de la cultura neerlandesa y estaban relacionados con el interés general de la población en los asuntos políticos y religiosos. Este interés era tal que tanto los libreros y los escritores asumían que su audiencia estaba al corriente de los hechos actuales ${ }^{57}$. A esto se debe sumar el hecho de que la propaganda en los Países Bajos no estaba al servicio del gobierno sino que solía ser el canal empleado para expresar la oposición a determinadas políticas del mismo, contrastando con lo habitual en otros territorios ${ }^{58}$.

Aunque es la disensión religiosa la parte más llamativa del conflicto y que sin los calvinistas la República no hubiera tomado su forma definitiva, pues el movimiento iconoclasta fue la primera forma de expresión del descontento con la Monarquía, los recelos autonomistas fueron fundamentales en la configuración de la revuelta.

55 SWART, K., "The Black Legend during the Eighty Years War", en KossManN, E.H. y Bromley, J.S. (eds.), Britain and the Netherlands: papers delivered to the fifth Anglo-Dutch historical conference. Some political mythologies, vol. V, La Haya, 1975 (p. 36-57), p. 37.

56 Pese a que ni Lutero y mucho menos Calvino defendieron en sus primeros escritos el levantamiento contra la autoridad establecida, lo cierto es que a partir de los conflictos confesionales en la década de 1530 de los principes luteranos con el Emperador Carlos V se fueron desarrollando dos teorías, la constitucionalista desde Hesse y la de derecho privado desde Sajonia, que pretendieron justificar la desobediencia al señor natural. SKINNER, Q., op. cit, p. 194-200. Algunas décadas después, algunos autores neerlandeses adoptaron la teoría del derecho privado. El derecho natural a la defensa propia y la máxima de que era lícito repeler la fuerza injusta por la fuerza fueron desarrollados por ciertos tratadistas neerlandeses. No obstante, en general, los calvinistas tendieron más hacia la linea constitucionalista; los autores neerlandeses aceptaron sobre la base de la Epístola a los Romanos que, al igual que los magistrados superiores como reyes y príncipes, los magistrados inferiores habían sido instituidos por Dios para proteger el bien y castigar el mal, rernitiéndose a los éforos de Esparta. Gelderen, M. van, The Political Thought of the Dutch Revolt (1555-1590). Cambridge, 1992, p. 108.

57 HARLINE, C. E., op. cit., p. 67.

58 SAWYER, J. K., op. cit, p. 2. La propia organización interna de la República, la falta de una autoridad central que pudiese llevar a cabo políticas de censura y la defensa feroz que hacian las diferentes provincias de su independencia en asuntos internos, permitió que la discusión pública e impresa de las acciones de gobierno del Estatúder y de los Estados Generales alcanzara cotas inimaginables en cualquier otro territorio europeo fuera de los periodos de guerra civil, tanto en el Imperio como en Inglaterra. 
La hoja ilustrada Imago Flandriae. Erinnerung an den Leser über gegenwertige Figur, Johannts Jannfontj, s.l., 1604, ${ }^{59}$ conecta los hechos acaecidos en 1468 en Flandes, atacando la acción de Carlos el Calvo contra las libertades borgoñonas, con la revuelta iniciada en 1568 y, finalmente, con la amenaza que suponian las tropas hispanas para la independencia de las Siete Provincias en el momento en el que se redactaba el panfleto. Esto nos indica la importancia que tuvieron en la lucha contra la Monarquía Católica y en la posterior configuración de la República la defensa de las libertades y los privilegios territoriales, lo que llevó al Cardenal Bentivoglio a afirmar que ningún pueblo amaba tanto sus libertades como los neerlandeses y a considerar la defensa a ultranza de las mismas la causa principal de la Revuelta ${ }^{60}$. El sostenimiento de los privilegios territoriales fue también el argumento más empleado por Guillermo de Orange, Marnix van St. Aldegonde y Jacob van Wesembeeke en sus escritos de los primeros años de la Revuelta ${ }^{61}$.

La discusión en torno a la Revuelta contra la Monarquía Hispánica y su influencia en la configuración de la «nación» neerlandesa ha estado presente en la historiografía desde el primer momento, pero el auge de la interpretación nacionalista tuvo lugar en el S. XIX. Desde entonces, la discusión se ha prolongado, influyendo las visiones históricas de algunos de los autores más relevantes que han estudiado la primera fase del conflicto, desde el decimonónico Robert Fruin hasta P. Geyl ${ }^{62}$. Sin

59 PAAS, J.R., op. cit., vol. 1, p. 158.

60 "Gli huomini [delle Provincie Unite] amano sopra modo la libertà, e perciò si mostrano tenacissimi de' lor privilegi; e di quì nasce, che siano facili andora ad insospettirsi, e facili ad alterarsi; e questa lor doppia facilità usata per instrumento da chi eccitò le turbulenze di Fiandra ne' nostri tempi, gli gece poi senza mota fatica ribellar in doppia maniera, et alla Chiesa Cattolica, et al Prencipe lor naturale.» BeNTIVOGLIO, G., Relatione delle Province Unite. Facsimile dell'edizione "elzeviriana», Brusselles, 1632. Ed. a cargo de S. MASTELLONE y E.O.G. HAITSMA MUI IER, Florencia, 1983, ff. 3-4.

61 Son los textos del Compromiso firmado en enero de 1566 por varios centenares de nobles e inspirado por John Marnix y Nicholas de Hames (ed. por Groen van Prinsterer en el ,4rchive ou Correspondance inedite... 1e serie, 2, p. 2), De beschrijvinge van den geschiedenissen inder religien saken toeghedragen in den Nederlanden (Jacob van Wesembeeke, 1569; Kn. 147.) y Verantwoordinge, verklaringhe ende waerschouwinghe des Princen van Oraengien (1 septiembre 1568), entre otros documentos.

62 Una interesante aproximación a las diferentes visiones historiográficas en torno a la Revuelta se puede encontrar en GroenVELD, S., «Image and Reality. The historiography of the Dutch Revolt against Philipp Il», en Schepper, H. de y Rietbergen, P.J.A.N. (eds.), España y Holanda. Ponencias de los coloquios hispano-holandeses de historiadores (1984-88). Madrid/ Nijmegen, 1993, pp. 37/80. 
entrar en presuntas configuraciones nacionalistas, desde la óptica de la Monarquía Hispana, lo que estaba en juego en las guerras europeas eran intereses religiosos, o, en palabras de Joseph Pérez, ideológicos, ya que se trataba de una lucha que intentaba poner fin a la herejía que iba extendiéndose por el territorio de la Cristiandad ${ }^{63}$. En el caso de Flandes esto se ve confirmado por las siguientes palabras de Felipe III:

"quiero que entendáis que por la defensa de mis hermanos [los Archiduques Alberto e Isabel Clara Eugenia] y que aquellos estados se reduzcan enteramente a la religión católica y no salgan del dominio de mis hermanos y de mi corona pondré y aventuraré los demás que Dios me ha encomendado y mi persona cuando los demás medios no aprovechasen y al Consejo se lo pareciese» ${ }^{64}$.

No obstante, la historiografía anglosajona tiende a minimizar la importancia de las motivaciones religiosas en el seno de la Monarquía Católica. Así, en relación a la no renovación de la Tregua de los Doce Años, Jonathan Israel rechaza el que la defensa de la catolicidad fuera el principal motor de la Monarquia ${ }^{65}$. Aunque redactada por católicos neerlandeses también en la hoja ilustrada Leichbegengnuß Des nunmehr zum Endegeloffenen und verstorbenen Treues in den niederländischen Provincien... (Claes J. Fischer, 1621), ${ }^{66}$ que lamentaba el final de la Tregua de los 12 años mediante la representación de un cortejo fúnebre, se cuestionaba el que la Monarquia Hispana persiguiese realmente el bien del catolicismo y lo mismo se mantiene en los panfletos de la polémica francesa de 1635.

\footnotetext{
63 Pérez, J., “Felipe II ante la Historia. Leyenda negra y guerra ideológica", en KameN, H. y PÉREZ, J., La Imagen internacional de Felipe II: "Leyenda negra" o conflicto de intereses. Valladolid, 1980 , p. 20-21. La misma valoración de la política de la Monarquia Cátólica subyace en toda la obra de Jover Zamora, J. M., 1635. Historia... Pero la mportancia de los motivos confesionales o ideológicos no era privativo de la Monarquía Hispánica; Craig Harline señala que, aun tratándose de la, según gran parte de la historiografia, "desideologizada" República Holandesa, la mayoria de autores de panfletos escribían por convicción y no como fuente de ingresos, siendo los impresores y vendedores los que obtenían mayores beneficios. HARLINE, C. E., op. cit., p. 106.

64 Carta del rey al Consejo en respuesta a la consulta hecha por éste al monarca 26 noviembre 1602, en Consultas hechas por el Consejo de Estado a su Magestad, en los años de 1600, sobre asuntos de Flandes y otros particulares" (1600-1629), BN, Mss. 11124, f.1r.

65 ISRAEL, J., "Un conflicto entre Imperios: España y los Paises Bajos, 1618-1648", en J. H. Ellot (ed.) Poder y sociedad en la España de los Austrias. Barcelona, 1982, p. 152.

66 HaRms, W., (ed.), Die Sammlung der Herzog August Bibliothek in Wolfenbüttel..., t. II, Munich, 1980, pp. 344-345.
} 
Si en el caso del Imperio se pueden separar las críticas al papado y a los jesuitas de las hechas directamente contra la Monarquía Católica, en las Provincias Unidas, los ataques calvinistas a la religión católica y a la Contrarreforma sí se pueden considerar como parte de la imagen que se tenía de la Monarquía Hispana, máxima representante del poder católico en las Provincias Unidas. Un ejemplo de crítica a la religión católica lo encontramos en Hier strjkt en swijmt voor Christus d' Antichrist... ${ }^{67}$ (Ámsterdam, 1638). En ella se denuesta a Ignacio de Loyola, al igual que a otros símbolos de la Iglesia católica. En otros muchos grabados se produce la equiparación de hispanos y representantes del catolicismo contrarreformista, especialmente los jesuitas pero también otras órdenes religiosas, como sucede en Wie Spannien mit Niderlandt umgangen/ und was es für aussgang genommen, $1610{ }^{68}$.

Las críticas a la religión católica y, más específicamente, a la forma de imponerla en las Diecisiete Provincias, fueron uno de los principales asuntos a los que hacía referencia la propaganda producida desde los rebeldes. Primero las invectivas se dirigieron contra la Inquisición, y se exigía un mayor grado de libertad religiosa, puesto que se esperaba aglutinar en torno a este argumento todos los movimientos de oposición a la Monarquía sin entrar en los aspectos religiosos y políticos que los separaban ${ }^{69}$.

En las Provincias Unidas el surgimiento de una conciencia nacional, y ésta de dudosa consistencia, parece la consecuencia, y no la causa, de la revuelta contra Felipe II. A través de los textos de la revuelta se constata una evolución de la imagen que los neerlandeses tenían de sí mismos y que se fue desarrollando en oposición a la idea de España que se iba configurando en la joven República ${ }^{70}$. Esta visión se conservaría

67 HaRms, W., (ed.), Illustrierte Flugblätter..., pp. 70-71.

68 PAAS, J.R., op. cit., vol.1, p. 256.

69 SWART, K., op. cit., p. 38/42.

70 Esta opinión es compartida por GroenVELo, S., «Natie en nationaal gevoel in de zes. tiende eeuwse Nederlanden", en Scrinium et Scriptura. Opstellen betreffende de Nederlandse geschiedenis aangeboden aan Professor dr. J. L. van der Gouw bij zijn afscheid als buitengewoon hosgleraar in de archiefwetenschap en in de paleografie van de verertiende tot de zeventiende eeuw aan de Universiteit van Amsterdam. Groningen, 1980, pp. 372/387 y en "Nation und "Fatria". Begriff und Wirklichkeit des kollektiven Bewusstseins im Achtzigjährigen Krieg", en Lademacher, H. y Groenveld, S., Krieg und Kultur. Die Rezeption von Krieg und Frieden in der Niederländischen Republik und im Deutschen Reich 1568-1648. Münster; New York, München, Berlin, 1998, pp. 77!09, DuKE, A., «From king and country to king or country?: loyalty and treascn in the revolt of the Netherlands", en Transactions of the Royal Historical 
pese al paso del tiempo, como se puede comprobar en numerosos libros históricos escritos en el $\mathrm{s}$. XVII, en los que confluyen en ocasiones dos imágenes, Batavia y la Revuelta contra la Monarquía Hispana, que alaban el amor de las Provincias Unidas a la libertad en contraposición a otros territorios, principalmente Castilla. La lucha de los bátavos por su libertad contra el poderosísimo Imperio Romano se empleaba como ejemplo para los nuevos libertadores de la "vaderland", siendo un modelo paradigmático de esta equiparación la obra de Hugo Grocio, Liber de antiquitate Republicae Batavicae que pretendia reforzar la independencia de la República retomando las afirmaciones de Erasmo en su Auris Batava (1508) y de Cornelius Aurelius en la Divisiekroniek (1517), y presentaba a la Batavia clásica como un pueblo de campesinos dispuestos a cualquier lucha con tal de preservar su libertad y remontaba la labor de los Estados en la defensa de las libertades, así como el pensamiento republicano, a la Antigüedad clásica ${ }^{71}$.

En su Advertencia.., el Príncipe de Orange afirmaba que durante los cincuenta años transcurridos desde que los territorios de España y los Países Bajos se unieran bajo el dominio de un mismo soberano, algunos grandes de España habían intentado obtener el poder de gobernar y tiranizar las prósperas provincias como hacían en los demás territorios, y que no habian cejado en el empeño de emplear todas las oportunidades posibles para engañar al benevolente príncipe para lograr sus fines ${ }^{72}$. Aquí tenemos una primera idea de la visión de los españoles en las Provincias Unidas sublevadas, en las

Society. 5th series, vol.32, 1982, pp. 113/135, SchamA, S., The Embarrassment of the Riches. An Interpretation of Dutch Culture in the Golden Age. University of Calitornia Press, 1988 , p. 69 y ss. y por KossmanN, E. H., "Some questions concerning Dutch National Consciousness", en SChePper, H. de y Rietbergen, P.J.A.N. (eds.), España y Holanda. Ponencias de los coloquios hispano-holandeses de historiadores (1984-88). Madrid/ Nijmegen, 1993, pp. $137 / 152$.

${ }_{71}$ HaItSma Mulier, E.O.G., "Het begrip "vrijheid" in de Nederlandse geschiedschrijving van de zeventiende tot de negentiende eeuw", en HAITSMA MuLIER, E.O.G. y Velema, W.R.E. (eds.). Vrijheid. Een geschiedenis..., Amsterdam, 1999, p. 217. Los estudios más interesantes sobre las ideas republicanas en la Revuelta son el ya citado de GELOEREN, M. van, The Political Thought... y Mout, M.E.H.N., "Ideales Munster oder erfundene Eigenart. Republikanische Theorien während des niederlandischen Aufstands", en KoEnigsBerger, H., (ed.), Republieken und Republikanismus im Europa der Frühen Neuzeit. Munich, 1988, pp. 169/194. Para la vinculación del pensamiento republicano neerlandés con la idea de libertad, resulta interesante RowEN, H., "The Dutch Republic and the Idea of Freedom", en Republicanism, Liberty, and Commercial Society, 1649-1776. Standford, 1994, pp. 310/340.

72 Kossmann, E.H. y Mellink, A.F. (eds.), op. cit., p. 84-85. 
que las quejas se dirigen a los ministros, pero no al monarca, y donde se menciona la tiranía y avaricia hispanas. Orange negaba que estuviese rebelándose contra el rey como tal y reconocía a Felipe II como su soberano; el blanco de la revuelta eran el Duque de Alba y los malos consejeros del monarca ${ }^{73}$. Esto ocurre también en la mayoría de las Geuzenliederen o canciones de los Mendigos del Mar, donde el rey es mencionado con mucha menos frecuencia que sus ministros, especialmente Alba ${ }^{74}$.

Cuando se mencionaba a Felipe II solía ser con relación a Guillermo de Orange, como sucede en el Wilhelmus, ${ }^{75}$ (ca. 1569), para resaltar las virtudes del Estatúder. En esta geuzenlied que terminó por convertirse en el canto del calvinismo neerlandés para acabar siendo el himno nacional, se presentan ya algunos de los rasgos que definirían las visiones de Felipe II en la propaganda anti-hispana en las Provincias Unidas durante las primeras décadas de la Revuelta, contraponiéndose siempre la visión positiva de Guillermo de Orange, así como la justificación de su resistencia. Si por una parte se recuerda la fidelidad del Príncipe al Monarca Hispano, por otra se recuerda la necesidad de obedecer a una autoridad superior a la terrena. Además se recalca la alta cuna de Guillermo, proveniente de "Keyserlicken Stam", lo que enlaza con las teorías del derecho de rebelión de los magistrados inferiores realizada por Calvino.

En los primeros momentos de la revuelta no podría decirse que $\mathrm{Fe}$ lipe II fuese un personaje muy atrayente para sus súbditos neerlandeses, pero era el Rey y, como tal, estaba investido del poder de la dignidad que representaba, algo de la máxima relevancia en una sociedad marcada por la estratificación estamental, en la que las interpretaciones del orden social se veian e interpretaban como derivaciones directas del plan divino y en la que la vinculación a los monarcas se pro-

\section{p. 162 .}

73 IsRael, J., The Dutch Republic. Its Rise, Greatness, and Fall, 1477-1806. Oxford, 1995,

74 O ghy Nederlanden seer $f e l$, fechada en torno a 1580 , es un ejemplo inaudito, pues en esa canción se considera al monarca el responsable de todo lo acaecido en las Provincias Unidas, sin que en ningún momento se haga mención de los defectos antropológicos de los españoles ni se recurra a la crítica a los ministros del rey. LEENDERTZ Jr., P. (ed.), Het Geuzenliedboek / naar de oude drukken uit de nalatenschap van E.T. Kuiper. Zutphen, 19241925, vol. 1, p. 309-310.

75 MiddendorP, H., (introducción y notas), Het Wilhelmus en andere geuzenliederen. Zwolle, 1940, pp. 18-23. 
ducía en virtud del derecho dinástico, y no condicionados por los principios de «nacionalidad» o de naturaleza ${ }^{76}$.

Por más que la propaganda tendiera siempre a atacar a personas y hechos concretos, resulta obvio que la Revuelta no estuvo dirigida solamente contra las iniquidades de la política religiosa o impositiva del Rey Prudente y sus ministros, sino contra la mayor parte de las tendencias de gran parte de las monarquías de la época, como son la centralización fiscal, la implantación de una burocracia profesional, el reordenamiento judicial y el ataque a los privilegios territoriales ${ }^{77}$. Así llegaron a condenar la creación de los nuevos obispados y la introducción de la Contrarreforma en las Provincias Unidas como atentatorio contra las libertades y privilegios de las mismas ${ }^{78}$. Este tipo de acusaciones acabó tomando una forma casi fija, mezclándolos con acusaciones raciales y religiosas, tal y como constata J. Polimann ${ }^{79}$.

Dentro de la defensa de los privilegios y las libertades territoriales se fue configurando el sentimiento nacional neerlandés, ya que desde los primeros momentos de la Revuelta el término "vrijheid» estuvo presente en todos los alegatos justificativos del movimiento, incluyendo dentro de este entendimiento las "vrijheiden", la "oude vrijheid" y la "vrijheid der conscientien» ${ }^{80}$. Así, la Revuelta fue, en los primeros momentos, una lucha en pro de las libertades, cuyos diferentes conceptos se fueron desarrollando y cargando de significado a medida que iban siendo desarrollados en los escritos políticos y que llevaron a la integración de Estados, libertades y "oude vrijheid" en un trinomio, convirtiéndose los primeros en los protectores y garantes de la conservación de los privilegios ${ }^{81}$.

En la Apología o defensa del muy ilustre príncipe Guillermo, por la gracia de Dios príncipe de Orange etc. contra el bando y edicto publi-

76 VOET, L., Felipe II, Guillermo de Orange.., p. 44.

77 Schama, S., op. cit., p. 62.

78 A Defence and True Declaration, en GelDeREN, M. van (ed.), The Dutch Revolt, p. 25.

79 Pollmann, J., op. cit., p. 79-80.

80 No obstante, al irse estabilizando la situación interna de la República, se produjo una división entre los autores más condicionados confesionalmente respecto a los demás, pues mientras que los primeros siguieron aferrados a la oposición libertad neerlandesa-tiranía hispánica, los segundos empezaron a concentrarse mucho más en los conceptos de libertad ciudadana y de cultos. SPIES, M., op. cit., p. 89.

81 GelDEREN, M.. van, “De Nederlandse Opstand (1555-1610): van "vrijheden" naar "oude vrijheid" en de "vrijheid der conscientien"”, en Haitsma MuLIER, E.O.G. y Velema, W.R.E. (eds.), Vrijheid. Een geschiedenis.., p.35 
cado por el rey de España (1581) ${ }^{82}$, presentada a los Estados Generales, se sigue reconociendo a Felipe II como Duque de Brabante, aunque se le reprocha que haya olvidado lo que prometió a Dios y al reino y las condiciones aparejadas a su rango ducal. Se recordaba al monarca que no era libre de hacer su voluntad en los Países Bajos como podía ser el caso en las Indias y que existían instituciones y leyes a las que se debía someter, esto es, las libertades del territorio. Al romper Felipe II de manera tiránica y arrogante los privilegios, Guillermo de Orange afirmaba que los principales nobles de las Provincias Unidas estarían traicionando a los Estados y a la nación si no se rebelaban contra el tirano. Esta argumentación aparece también en el Acta de Abjuración ${ }^{83}$, lo que nos muestra de nuevo el interés de los neerlandeses en justificar la rebelión contra su señor natural centrando el debate en la defensa de las libertades de las provincias.

Un ejemplo anterior lo encontramos en la canción Ras seventhien Provincen, ${ }^{84}$ incluida en la campaña de propaganda iniciada por Guillermo de Orange en la primavera de 1572 para mover al levantamiento de las provincias meridionales de los Países Bajos. En ella se retoman muchos de los lugares comunes de la crítica anti-hispana en las Provincias Unidas y se reitera la imagen del de Orange como súbdito fiel que ha sido injustamente perseguido por el tirano; se repiten las acusaciones de crueldad de los hispanos e, incluso, yendo más allá de lo habitual, se considera a los partidarios de la Monarquía Católica rebeldes, además de servidores del Anticristo. Por otra parte aquellos que se oponían al dominio de la Monarquía Católica eran los defensores de la palabra de Dios y del derecho territorial o "tLants Rechten".

Argumentaciones muy similares encontramos en la canción compuesta para celebrar la toma en febrero de 1574 por las tropas de Guillermo de Orange de Middelburg, última ciudad de Zelanda en manos de la Monarquía Hispánica, Wilt nu ghy Nederlanden, ${ }^{85}$ instando a la rebelión a aquellos territorios que aún seguían bajo del dominio del Rey Prudente.

A los alegatos en pro de la lucha por la libertad y el derecho se sumó una balbuceante idea de nación que pretendía convertir la «va-

\footnotetext{
Kossmann, E.H. y Mellink, A.F. (eds.), op. cit., p. 212.

lbid., pp. 216-228.

LeENDERTZ Jr., P. (ed.), op. cit., vol. 1, p. 121-122.

íbid., vol. 1, p. 207-208.
} 
derland" en un poderoso foco de adhesión para aquellos que debian luchar, y soportar la lucha ${ }^{86}$, haciendo que se involucrasen en una guerra por la patria, concepto éste que debía servir a los ciudadanos para soportar los males del enfrentamiento y que se reflejaba en la época de los grandes sitios, en torno a 1575, en medallas y monedas, nuevos ejemplo de la importancia de los instrumentos propagandísticos en la revuelta holandesa ${ }^{87}$.

Otro de los rasgos que contribuyeron a conformar el sentimiento nacional neerlandés fue la sustitución de la figura de los Habsburgo por la dinastía Nassau, que se convirtió así en uno de los símbolos patrios, aunque sin llegar a investirlos nunca de la sacralidad y los poderes inherentes a la institución real ${ }^{88}$.

Este cambio de orientación, de la justificación de la Revuelta contra el señor natural a los intentos de crear, siempre con muchos matices, una "nación" neerlandesa se puede rastrear fácilmente en los pasquines. Asi, los escritores de panfletos pasaron de dirigirse preferentemente al público internacional, especialmente a príncipes y nobleza de los territorios europeos, como es el caso de la Apología de Guillermo de Orange, a enfocar más sus escritos hacia un público neerlandés, una vez que la República se iba asentando. Este cambio también se reflejó en la profundidad intelectual de los panfletos, pues, siguiendo las recomendaciones del Príncipe, se tendió a reducir y simplificar obras como las de van Weesembeek para llegar al público neerlandés ${ }^{89}$.

Además de reformular antiguos mitos territoriales como es el caso de Batavia para adaptarlos a las nuevas realidades, los neerlandeses se vieron en la necesidad de combinarlos con nuevos símbolos fruto de la escatología calvinista y que llevaron a los habitantes de los $\mathrm{Pa}$ íses Bajos del Norte a configurarse como un nuevo pueblo elegido.

86 Simon Groenveld ha analizado las consecuencias de la Guerra de los Ochenta Años sobre la población neerlandesa en «Mars und seine Opfer. Über Organisation und Folgen des Krieges in der Republik,", en LADEMACHER, H. y GroenveLD, S., Krieg und Kultur..., pp. 21/54.

87 Schama, S., op. cit., p. 69.

88 Algunas de las atribuciones que en los demás territorios de la Cristiandad ostentaban los monarcas quedaron en las Provincias Unidas sin sujeto que las ejerciera, como es el caso de la potestad de ennoblecer a plebeyos, que no fue ejercida ni por el estatúder ni por los Estados Generales. NIEROP, H.F.K. van, The nobility of Holland. From knights to regents, 1500-1650. Cambridge, 1993, p. 33.

89 HARLine, C.E., op. cit., p. 25. 
Felipe II se convirtió en trasunto del Faraón e, implícitamente, Guillermo de Orange pasó a ser un nuevo Moisés, lo que se repitió en torno a 1630 con Gustavo Adolfo de Suecia, lo que nos vuelve a señalar lo persistentes que resultaban ciertas imágenes creadas 0 difundidas a través de los pamfletten. Otra de las referencias habituales en las Geuzenlieden y otras obras cuyo fin era la justificación de la Revuelta y la popularización de los argumentos empleados para ello, era el considerar a Guillermo de Orange como un nuevo David, algo que aparece en el Wilhelmus ${ }^{90}$. Esta identificación se repite en muchas ocasiones en las canciones de los Mendigos del Mar, por ejemplo en Alsmen schreef duysent vijfhondert... ${ }^{91}$, letrilla escrita 1568, donde se retoman las equiparaciones con la Historia Sagrada, siendo lo más novedoso que aquí se introduce también la comparación del Duque de Alba con Nerón.

Este tipo de caracterización pervivió tras el asesinato del príncipe, como se puede ver en Ein new und Christlich Liedt, gemacht zu ehren und wolgefallen dem Durchleuchrigen und Christiluceh Kriegsfursten Mauritio Graven von Nassaw..., Matthias Quadus, $1605^{92}$. Este tipo de equiparaciones de la presunta nación neerlandesa con la judía no fue privativo de los calvinistas; alguien tan denostado por los partidarios de la Reforma radical como D. $V$. Coornhert recurrió al pueblo de Israel como alter ego del neerlandés en su lucha contra la Monarquía Católica en su Comedie van Israel. Vertonende Israels zonden, straffinghe, belydinghe ghebedt, beteringhe ende verlossinghe, uyt het thiende capit. Judicum: Als een klare spieghele der teghenwoordighen Allegorie op de situatie van de Noord. Ned. in 1575, geschreven in hetzelfde jaar, Gouda, 1590. Lógicamente, también encontramos este tipo de identificación entre autores de fuertes convicciones calvinistas, como es el caso del médico Jacobus Viverius, Den spieghel van de Spaensche tyrannie: waer by ghevoegt is eene vreughdighe vieringhe over het veroveren van ... Rijnberck, Amsterdam, 1601, Kn. 1167.

Así, a través de elementos antiguos o de presunta antigüedad, los neerlandeses fueron creando una nueva identidad territorial, fruto y justificación de lo que era insostenible, la rebelión contra la autoridad

MidDENCORP, H., op. cit., p. 21.

LeENDERTZ Jr., P. (ed.), op. cit., vol. 1, pp. 62-66.

PAAS, J.R., op. cit., vol.1, p. 177. 
real. Los elementos que conformaban esa naciente conciencia patriótica estuvieron en constante proceso de invención, embellecimiento y recreación, pero sin reconocer en ningún momento lo novedoso de los mismos sino, al contrario, reivindicando la presunta antigüedad de estos símbolos y de lo que representaban y defendían ${ }^{93}$. Todo esto se combinaba con la idea de pureza que emana del calvinismo y que cristalizaba en los panfletos y grabados de la época en la creación de la figura de la "doncella holandesa", presente en Al Heeft Duc d'Alba nederlant naect gheschoren... ${ }^{94}$, donde se retrata a "Belgica" como una muchacha retenida contra su voluntad por el Duque de Alba, que también tiene a sus pies a una figura masculina, hambrienta y empobrecida que representa a la "Plebs". Todo esto se contrapone con la riqueza y la justicia que traerá Guillermo de Orange a las Provincias Unidas ${ }^{95}$.

Las críticas a Felipe II se hicieron más violentas a medida que transcurrió el tiempo tras el inicio del a Revuelta y se vio que la solución conciliadora era cada vez menos plausible; tanto él como el de Alba permanecieron, no obstante, como hitos de odio, empleándose en numerosas ocasiones los mismos argumentos para denostarlos. Un ejemplo de las críticas realizadas contra el Duque de Alba es Her nimpt mit gewalt dem rychtom von dem Land... (ca. 1570, texto en bajo alemán y francés) ${ }^{96}$, un grabado que consta de dos partes. En una aparece el Duque de Alba sentado en un trono, cogiendo toda la riqueza de las provincias y comiéndose a un niño, referencia a las acusaciones de judaísmo que se hacen a la Monarquía Hispana en general y a Fernández de Córdoba en particular ${ }^{97}$, al lado de un monstruo de tres ca-

\footnotetext{
93 Schama, S., op. cit., pp. 67-71.

94 Harms, W., (ed.), Die Sammlung der Herzog August Bibliothek in Wolfenbüttel..., t. II, Munich, 1980 , p. 46-47,

9 Una posible prueba de la falta de existencia de un sentimiento nacional neerlandés en los primeros momentos de la revuelta podría ser el hecho de que entonces el sujeto atacado no era "España", sino que los neerlandeses afirmaban intentar ser buenos súbditos de su príncipe, malquistado contra ellos por obra de los malos ministros.

96 HaRms, W., (ed.), Die Sammlung der Herzog August Bibliothek in Wolfenbüttel..., $\mathrm{t}$. II, Munich, 1980, p. 142-143.

97 Como señala Judith Pollmann, en las publicaciones de Brederode y sus correligionarios a principos de 1568 se presentaba al Duque de Alba como "nuestro enemigo moro" o "cripto marrano". Se produce así una interesante transposición de imágenes del enemigo. Si la Monarquía Católica demonizó a los judíos y a los moriscos a través de mitos como el del Niño de la Guardia, ese mismo tipo de símbolos constituyó parte importante de las acusaciones realizadas contra los hispanos en los Países Bajos. Pollmann, J., op. cit., p. 77.
} 
bezas, la de Granvela, que también muerde del niño, y la de dos de los Guisa, Luis I de Lorena y su hermano Carlos. A sus pies están dos cadáveres decapitados, que representan a Egmont y Horn, los dos principales mártires de la República. En la otra aparece Felipe II, en una imagen aparentemente más neutra, rodeado de un obispo y un inquisidor y con dos monjes a sus pies, mientras que en segundo término se presentan acciones calvinistas. El texto plantea la crueldad del Duque y que Felipe II, por haber seguido los consejos de obispos e inquisidores, ha infringido grandes dolores a los Países Bajos, lo que implica retomar los argumentos de la Advertencia... Se retoma aquí la idea de que los principales culpables de las malas acciones de los reyes son los consejeros de los mismos, algo que en las Provincias Unidas pervive claramente hasta el Acta de Abjuración y que se puede incluso encontrar en fechas tan tardías como 1604. En el grabado Quando obstetricabitis hebreus et partus tempus advenerit... Éxodo, 1.16 (Hendrik Goltzius, La Haya, 1604) ${ }^{98}$ se reformula el mito de Salomón, que deja de ser el símbolo de la Justitia y nos lleva a un rey que se deja influir por consejeros no aptos para ello, además de implicar el rechazo a un monarca que no se interese por escuchar a todas las partes. Salomón está representado como un joven, por lo que puede tratarse de una alegoría de Felipe III, aunque también es posible interpretarlo como un símbolo de la figura del Archiduque Alberto y una crítica a su carencia de plena soberanía.

Se hacen nuevas críticas a Alba y a la represión religiosa católica en Hie kan man warhafftig sehen für ewigen gedächtniss...(1569) ${ }^{99}$, en la que se detallan las crueldades de la Inquisición, las torturas y ejecuciones por mandato del Duque, se presenta la entrada de los tercios en Bruselas (1567), y se retrata a Granvela, al que se considera como verdadero inductor de las acciones represivas llevadas a cabo por la Monarquía Hispana, y al Duque de Alba siendo recompensados por sus acciones por el diablo, mientras mantienen encadenadas y humilladas a las Diecisiete Provincias. Inciden en esa visión muchos otros grabados, como Belgicae delaceratae lamentatio, (Ambrosius Francken, ca. 1570) ${ }^{100}$, que representa el ataque de los soldados españoles

${ }_{98}$ Harms, W., (ed.), Die Sammlung der Herzog August Bibliothek in Wolfenbüttel..., t. II, pp. $130-131$.

99 HaRMS, W., (ed.), Illustrierte Flugblätter..., pp. 144-145.

100 lbid., pp. 140-141. 
bajo el mando del duque de Alba a "Belgica", que representa al conjunto de los Países Bajosy se critica la avaricia y la ambición de los españoles, visible en los saqueos.

En la hoja volante titulada Enuie, Ambition, Volupté, Tyrannie..., (Theodor de Bry, Frankfurt, ca. 1568-1572) ${ }^{101}$, se presenta la oposición entre Guillermo de Orange y el Duque de Alba, siendo el primero la imagen de todas las virtudes y bendecido por la mano de Dios mientras el segundo, rodeado de las personificaciones de la Envidia, la Lujuria y la Falsedad, representaba para los neerlandeses la Tiranía. El texto que acompaña al grabado aparece en francés, latín y neerlandés y el que esté además editado en el Imperio muestra la vocación de internacionalidad en la difusión del mismo y, quizá, la voluntad, dadas las fechas, de influir en el partido hugonote francés. Otro ataque contra la figura de Alba lo encontramos en Siet hier thooft medusa wreet Tyrannich..., (Phillipp Galle y Jacques Jonghelinck, Amberes, 1571) ${ }^{102}$, sin que los atributos de Fernando Álvarez de Toledo sean modificados con respecto a grabados anteriores.

En la poesía alemana también aparece este hito del odio antihispano, el Duque de Alba. Así Christian Hofmann von Hofmannswaldau le dedica el siguiente epitafio: «Yace aqui el sanguinario que nunca halló sosiego/ hasta que al fin la muerte nueva orden le dio:/ y al desnucarle dijo: muere ya/ porque si no aun en matar me vencerias ${ }^{103}$.

Todas estas críticas son el fruto de la presunta idea del «Duque de Hierro" de crear "un mundo nuevo", en el que no habría lugar para las constituciones libertarias ni demás libertades territoriales, para lo que se valió de muy conocidas y difundidas, tanto en la propaganda de la época como en la historiografía posterior, medidas coercitivas y que hacen que aun en la actualidad se le considere un hito de brutalidad, cosa que se refleja incluso en la historiografía neerlandesa de carácter menos nacionalista ${ }^{104}$.

Además de atacar a la Monarquía Hispánica, las Flugblätter también celebran las victorias de los «rebeldes». En Gleych wie Gott inn fur

101 ibid., pp. 44-45.

102 libid., pp. 49-51.

103 QuintanA, A., op. cit., p. 378-379.

104 Esta visión extremadamente negativa del Duque de Alba la encontramos incluso en Gelderen, M., van, De Nederlandse Opstand..., p. 34. 
lettner zeytt... atribuido a Hendrik Golzius, $1578{ }^{105}$, se hace referencia a la decadencia del poder hispano en las Provincias Unidas tras la muerte de D. Juan de Austria y de Luis de Requesens, cuyos cadáveres se representan a ambos lados del asiento en el que Alba dormita, ignorando que por ambos lados se acercan los dos libertadores de "Belgica»; por la izquierda el Archiduque Matías, acompañado de una figura que representa la "dignitas» y por la derecha el Príncipe de Orange y la imagen de la "virtus", todo esto bajo el lema de "Liberte libertatae» referido a "Belgica», que esta vez no es ni una doncella ni un león, sino un caballo. Lo que se omite en esta representación son las crecientes disensiones entre los bandos católico y protestante de los Países Bajos, que en 1578 estaban desarticulando la unión fruto de la Pacificación de Gante de 1576.

Las figuraciones de España siguieron siendo similares tras la muerte de Felipe II. En Leo Belgicus (Georg Keller sobre diseño de Johannes Saenredam, 1601) ${ }^{106}$ se recoge la derrota de las tropas de Francisco de Mendoza y la prisión de éste a manos de Mauricio de Orange en la batalla de Nieuwpoort en 1600, reforzándose la imagen de «Belgica» como la patria de la libertad y baluarte de la verdadera religión, así como de las "Prudentia", la "Concordia" y la "Vigilantia". Todo esto lleva a ver la victoria de los neerlandeses como un logro moral más que bélico.

La misma idea subyace en la antes mencionada Ein new und $\mathrm{Ch}$ ristlich Liedt,..., canción en la que se presenta a Mauricio de Nassau como ejemplo de virtudes, enfrentadas, aunque sin nombrarlas, a las lacras de los reyes hispanos; se le presenta como el verdadero defensor de la palabra de Dios frente a las iniquidades del enemigo, que no es otro que la Monarquía Católica. En este mismo poema se dedica una estrofa a describir los defectos hispanos con la intención de movilizar a todos los habitantes de las Siete Provincias a favor de la política liderada por el estatúder, haciendo referencia al hecho de que, una vez liberados del yugo hispano, deben poner su carne y su sangre al servicio de la causa para mantener y extender al resto de las provincias la liberación del tirano.

105 HaAms, W., (ed.), Die Sammlung der Herzog August Bibliothek in Wolfenbüttel..., 1.11 , Munich, 1980 , pp. 66-67.

106 libid., pp. 122-123. 
Las críticas a los comandantes españoles en los Países Bajos no se limitaron al Duque de Alba, como se puede comprobar en la poesía de Joost van den Vondel, el principal poeta neerlandés del s. xvII, que acompaña al grabado Stedekroon van Frederick Henrick Prince van Oranien, \& c. (Ámsterdam, 1632) ${ }^{107}$, donde se describe a Alejandro Farnesio como una serpiente diabólica venida de ultratumba para envenenar al mundo pero condenada a la derrota por el príncipe de Orange. No obstante, en este panfleto se intentó evitar un posicionamiento confesional porque en los territorios que se estaban conquistando $y$ los que se esperaba asediar la mayoría de la población era católica. Aparece así una diferenciación entre «España» y el catolicismo pese a los intentos desde la Monarquía Hispana de que fueran equivalentes. Esto ya se encuentra esbozado en la Apología de Guillermo de Orange, el cual afirmaba que entre los católicos se encontraban muchos hombres honestos y patriotas, pese a que sobre ellos siempre pesase la sospecha de connivencia con los españoles, lo que no sucedía con los adscritos a las demás religiones y confesiones. Esto demuestra que la familia de Orange estuvo habitualmente más interesada en ampliar el territorio rebelado que en preservar la pureza religiosa, calvinista, de la República, de ahí la actitud de Friedrik Hendrik de ofrecer en la década de los treinta del s. XVII a las ciudades conquistadas mantener el culto católico sin restricciones de ningún tipo, pese a la oposición de los gomaristas ${ }^{108}$. Este interés por no alejarse a los católicos moderados nos explica porqué se hizo en ocasiones, tanto en el Imperio como en los Países Bajos del norte, más hincapié en una presunta nacionalidad amenazada que en los conflictos confesionales, ya que los argumentos xenófobos ofrecían la posibilidad de reforzar la propaganda de los sectores reformados, sin que eso significase enfrentarse a los católicos moderados con unas publicaciones radicalmente anticatólicas.

Esto también nos lleva a comprender por qué en los Paises Bajos se dio tal defensa de la necesidad de mantener la libertad de cultos; existe una fuerte necesidad de «tolerar» cuando no se encuentran absolutos de referencia, $y$, al no ser el calvinismo la única confesión, surgió la necesidad de explorar otras soluciones que fueran más allá que la de la imposición o del cuius regio. Sin embargo todos los grupos

\footnotetext{
107 libid, pp. 478-479.

108 ISRAEL, J., The Dutch Republic..., pp. 489 y ss.
} 
sociales coincidian en que lo deseable era que la población compartiera al menos unos mínimos en materia religiosa. Para conseguir la mayor uniformidad posible en ese campo y al no contar con el apoyo efectivo de los regentes para la persecución de los disidentes, la lglesia y los predicadores, al igual que muchos de sus contemporáneos, emplearon la propaganda, violando incluso las prohibiciones de los sinodos y publicaban anónimamente para no tener que pasar la censura previa de los tribunales eclesiásticos.

Estas actitudes no eran privativas de los Países Bajos; los naturales de Francia también conocían bien el poder de manipulación que tenían las palabras y la información, especialmente la impresa. Esto se reflejó claramente en el intenso conflicto interno que tuvo lugar en ese país entre 1614 y 1617 . Considerar la política como un proceso en el que se ganaba o perdía influencia en la medida en la que se podían manipular e influir las percepciones e impresiones de los lectores era algo presente en el s. XVII, lo que nos indica la existencia de un mundo perfectamente consciente de la importancia del control de los medios de comunicación ${ }^{109}$.

Volviendo al papel de los religiosos en la publicística neerlandesa, otra de las razones que les llevaban a publicar panfletos era el deseo de modificar la indiferencia gubernamental a la hora de establecer una política religiosa firme en defensa del calvinismo más ortodoxo, si bien esto podía crear tensiones con el poder político. Pese a las posibles instrumentalizaciones de la imprenta por parte de los clérigos, desde los primeros tiempos de la Reforma un importante número de publicaciones en forma de hoja volante eran sermones y demás actos de predicación ${ }^{110}$.

Como se puede constatar, los párrocos estuvieron lejos de identificarse con las actitudes de tolerancia que supuestamente caracterizaban a las Provincias Unidas ${ }^{111}$. Además, y pese a la tradicional imagen

109 SAWYer, J. K., op. cit., p. 15

110 Una aproximación al tema se encuentra en MOELLER. B., «Einige Bemerkungen zLum thema: Predigten in reformatorischen Flugschriften", en KOHLER, H.J. (ed.), Flugschriften als Massenmedium..., pp. 261/268.

111 Dentro del debate acerca de los límites de la tolerancia y de la libertad en las Provincıas Unidas, me gustaría señalar algunas obras que han tratado el tema. Por una parte tenemos las aportaciones de H. SCHILLING, "Calvinismus und Freiheitsrechte. Die politisch-theologische Pamphietistik der ostfriesisch-groningischen "Patriotenpartei" und die politische Kultur in Deutschland und in den Niederlanden", en Bijdragen en Mededelingen betreffende 
de las Siete Provincias como la cuna de la libertad religiosa, lo cierto es que, una vez terminó la necesidad de mantener a la población unida en contra del enemigo común, las inquietudes y diversidades confesionales surgieron claramente en el enfrentamiento entre arminianos y gomaristas y el intento de estos últimos de imponer soluciones que pasaban por la imposición. El hecho de que finalmente el partido más dialogante y "tolerante» acabase haciéndose con el control de las principales ciudades holandesas, no así en Zelanda, no nos debe hacer olvidar que primero se intentó suprimir las divergencias por la fuerza antes de iniciar una política de aceptación, más o menos oficial, de las diferentes confesiones ${ }^{112}$.

Con todo esto se puede constatar que el calvinismo más ortodoxo era, tanto antes como después de 1609 , el partido más agresivo y el que más producciones iconográficas realizó, sobre todo el núcleo más contrario a la tregua. En la obra teatral de Jacob Duym, Een Bewys dat beter is eenen goeden Crijgh, dan eenen gheveynsden Peys, Leiden, 1606, dedicada a Johan van Oldenbarnevelt, se expresan claramente los argumentos por los que se debía prolongar la guerra. Así Duym recomienda en la dedicatoria de su comedia a las Provincias que firmasen la paz entre ellas y fueran conscientes de que nada bueno les podría venir de los hispanos, ya que éstos no buscaban otra cosas que extender el dominio de su rey por toda la Cristiandad con apoyo de los jesuitas y del Papa, además de señalar que si la Monarquia Ca-

de Geschiedenis der Nederlanden, v. 102 (1987), pp. 403/434, y el volumen fruto del coloquio "Les Pays-Bas, carrefour de la tolérance aux Temps-Modernes", The Emergence of tolerance in the Dutch Republic, eds. C. Berkyens-Stevelinck, J. Israel and G.H.M. Posthumus MeYJES. Leiden, N.Y., Köln, 1997.

112 La acritud de las disputas teológicas puede comprobarse por la gran cantidad de panfletos atacando a los que se veía como traidores y tibios en materia de religión, como en $\mathrm{Na}$ erder openinghe van een hooch-wichtighe sake/ betreffende de wel-vaert van ons bedroeft Vader-landt..., s.l., 1618 (Kn. 2650), donde se rechaza la renovación de una tregua con la Monarquia Católica, siempre desde argumentos religiosos; se les denomina a los hispanos "Godtlose" (impios), que quieren levantar un nuevo dominio y se considera al mismo enemigo a ateos, epicúreos, libertinos, papistas y, en suma, a todos los que no acatan plenamente la religión reformada, potenciales enemigos del Estado. Acaba el pasquín con una advocación a Dios de que ayude a derrotar a los enemigos internos tan gloriosamente como se ha derrotado a los hispanos. En otros se termina acusando a Oldenbarnevelt de connivencia con el proyecto jesuítico, como en Arminianischer Irrwagen/welchen/als ihn die Jesuiten nach Rom führen wollen...,1619. PAAS, J. R., op. cit., vol. 2, p. 196. Otros en PAAS, J.R., op. cit., vol. 2, p. 165-170, KNUTTEL, W.P.C., Catalogus van de pamphletten-verzameling berustende in de Koniklijke Bibliotheek's. Gravenhage, 1889-1920, vol. 1, pp. 384-385, 399$404,414-415,437-450,471-481,517-538$. 
tólica había demostrado sus impulsos tiránicos cuando las provincias habian permanecido obedientes, qué no haría tras habérsele enfrentado. Además de expresar en la edición impresa de la obra el rechazo a la Monarquía Hispánica, el simple dramatis personae de la misma comedia indicaban claramente la intención del autor, en tanto que a las dos figuras alegóricas que son Bloed-dorstlich ghemoed (Actitud sanguinaria) y el wraeck-gierich hert (Corazón vengativo y avaricioso) se oponen t'Verplichte Land, (tierra comprometida) los Gemeyne Staten (Estados Generales) y el Trouwen Raed (fiel consejo) ${ }^{113}$.

Una actitud similar se encuentra en el panfleto Waerachtich ende cort verhael vande groote Ambitie... des Conings van Hispaengien/ Philips den tweeden van dier Namen... Ende wat voor der bedenckinge dat in d' onderhandelinghe van dese aenstaende Vrede is, s.l., 1608, Kn. 1480 , obra debida a "un amante de la libertad de su patria». Aquí aparecen recogidos algunos de los lugares comunes propios de la Leyenda Negra, como es el señalar las aspiraciones de Felipe II y de sus descendientes a la Monarquía Universal bajo el manto de protectores de la Iglesia católica.

Un claro ejemplo de que la actitud anti-hispana del calvinismo más agresivo no varió tras la interrupción de las hostilidades lo encontramos en el grabado realizado por Willem Buytewech en 1615 por encargo de un patricio del partido contrario a Oldervarenveld, artífice del alto al fuego. En torno a la firma de la paz de Münster, la actitud calvinista, nuevamente, distó mucho de ser conciliadora ${ }^{114}$.

Otra acusación realizada frecuentemente en los panfletos financiados desde los rebeldes era que desde la Monarquía Hispana se pretendía emplear los Países Bajos como fuente de recursos para sus propios intereses, alegando que rio buscaban, y desde el principio no

113 Los alegatos en pro de una "buena paz» que se sabe imposible por la iniquidad hispana fueron comunes en los años anteriores a la firma de la Tregua de los Doce Años. Un ejemplo es Schuyt-Praetgens, Op de Vaert naer Amsterdam, tusschen een Lantman, een Hovelinck, een Borger, ende Schipper, s. I., 1607-8. (Kn., 1450), donde se rechaza la paz con la Monarquía Católica por la falsedad de los legatarios hispanos y por la intención de que los neerlandeses cediesen sus posiciones en las Indias, además de negar la posibilidad de que se autorizase el culto católico en las Siete Provincias.

114 Un interesante análisis de las actitudes de Zelanda, principal bastión calvinista y de oposición a la paz lo encontramos en KLUIVER, J.H., De Souvereine en Independente Staat Zeeland. De politiek van de provincie Zeeland inzake vredesonderhandelingen met Spanje tijdens de Tachtigjarige oorlog tegen de achtergrond van de positie van Zeeland in de Republiek. Middelburg, 1998. 
habian buscado otra cosa que empobrecer el territorio y acabar con todas sus riquezas ${ }^{115}$. Este mismo argumento se encuentra, aunque haciendo referencia a varios personajes, en Die Khue auB Nider Land, (Colonia, 1587) ${ }^{116}$ donde se representa a los Países Bajos como una vaca de la que el duque de Anjou tira mediante una cuerda, Felipe II intenta retenerla por el rabo, los ingleses, representados por el conde de Leicester, la ordeñan "biß an das blut" aunque la res tire el cubo y se derrame la leche y Guillermo de Orange, calificado de germanus præripuisse, intenta llevársela tirando de los cuernos. Si bien la imagen resulta ambigua, el poema que acompaña al grabado considera que la vaca pertenece realmente a Felipe II, que cuenta además con la pericia militar de Alejandro Farnesio, Duque de Parma ${ }^{117}$.

Los neerlandeses también desconfiaban de la veracidad de la búsqueda de paz de los hispanos en el conflicto que los enfrentaba con las provincias rebeldes. El grabado Iberae Naeniae, $1608{ }^{118}$, afirma que las conversaciones de paz entre España y las Provincias Unidas son vanas, fútiles. Se representan en un medallón los retratos de los cinco plenipotenciarios, Jan Neyen, Lodewijk Verreycken, Ambrosio Spínola, Jean Richardot y Juan de Mancicidor. Debajo de ese medallón y como símbolo de la corta duración que se augura a la paz aparecen dos niños jugando con pompas de jabón; entre las que explotan frente a una ciudad en llamas está la que lleva el letrero Pax.

El sentimiento es similar al que expresa la mencionada comedia de Jacob Duym, el cual considera mejor una buena guerra que una mala paz, que sería la que se firmase con la Monarquía Católica, dada la falsedad de sus intenciones y que se trata de un reino más dispuesto hacia la guerra que hacia la paz, que haría que los neerlandeses perdiesen el acceso a la palabra divina y a la libertad, de ahí que se prefiera la guerra por muchos desastres que acarree ${ }^{119}$. Este mismo ar-

115 Vertoog ende Openinghe..., en GELDEREN, M. van (ed.), The Dutch Revolt, p. 118.

116 Harms, W., (ed.), Die Sammlung der Herzog August Bibliothek in Wolfenbüttel..., t. II, Munich, 1980, pp. 86-87.

117 Este grabado contrasta con la imagen que, según Schama, se pretendia difundir mediante el símbolo de la vaca holandesa, pues claramente no se trata aquí de una imagen pacífica y de alegría por la prosperidad del territorio. SCHAMA, S., op. cit., p. 71.

118 Harms, W., (ed.), Die Sammlung der Herzog August Bibliothek in Wolfenbüttel..., t. II, Munich, 1980, pp. 140-141.

119 DuYM, J., Een Bewys dat beter is eenen goeden Crijgh, dan eenen gheveynsden Peys. Leiden, 1606, p. 56. Kn. 1345. 
gumento fue empleado por Gustavo Adolfo y su canciller Oxenstierna para intentar convencer a los príncipes reformados alemanes a finales de 1631 de lo inconveniente que resultaria la firma de una paz separada con el Emperador ${ }^{120}$.

No obstante, la sinceridad de los deseos de las provincias rebeldes de alcanzar una tregua o paz duraderas eran también dudosas, como muestran las diferentes ediciones de la hoja ilustrada In Praesentem Icona, In Qvo Belli Statvs, qvod nvnc in Beligio..., $1607^{121}$, (edición bilingüe latín-alemán) pues, aunque se trata en el texto con relativo respeto al rey hispano, al que se le da el título de "serenísimo", lo cierto es que la imagen que acompaña al discurso valora de manera muy diferente a los generales católicos Spínola y a Bucquoi con respecto a Mauricio y Guillermo de Nassau, ya que los primeros son representados como símbolos del impulso guerrero que había asolado las Provincias Unidas, en tanto que los comandantes de las Provincias Unidas tan sólo se defienden de la amenaza de la «araña», ejemplo de juego etimológico en lenguas germánicas con el apellido de Spínola. Los representantes del poder militar hispano se ven además acompañados de una figura que presenta dos caras, clara alusión a la duplicidad que se achaca recurrentemente a la Monarquía Católica, pues no se debe olvidar que en las Flugblätter publicadas durante los años de la tregua se expresaba frecuentemente la opinión de que la Monarquía Hispana habia llegado a ese acuerdo como pretexto para preparar la invasión de las provincias septentrionales ${ }^{122}$.

La actitud un tanto ambigua en torno a las negociaciones previas a la firma de la Tregua de los Doce Años se repite en los panfletos que hacen referencia a la actividad mediadora de el padre Johann de Ney, In pacificationem Hispano Belgicam, eiusque tractationis Legatum primarium P. loannem de Ney..., 1607 y Beschreibung/ der fröhlichen/ guten/ und gewünschten Bottschafft unnd newen Zeitung/..., $1607^{123}$.

120 Suvanto, P., Die deutsche Politik Oxentiernas und Wallenstein. Heisinki, 1979, p. 45.

121 PAAS, J.R., op. cit., vol. 1, pp.194-197 ofrece diferentes versiones de este grabado.

${ }_{122}$ En la Monarquía Católica también se reaccionó negativamente a la tregua, como prueban los escritos de Quevedo, Guillén de la Carrera y demás autores analizados por Jover Zamora, J. M., en 1635. Historia de una polémica... Jonathan Israel considera que "La convicción general en el mundo ibérico de que la tregua era un desastre se basaba sobre todo en el hecho patente de que los años de la tregua habian coincidido con una transformación de la relación hispano-holandesa en desventaja para España." ISRAEL, J., Un conflicto entre Imperios, p. 149.

1̌3 PAAS, J.R., op. cit., vol. 1, pp. 198-199. 
En ellos, si por una parte se alientan las conversaciones, por otra no se deja de señalar el hecho de que el Leo Belgicus se hallaba encadenado por los Habsburgo, representados aquí por Margarita de Parma, y que gracias a los Geus (representados por un ganso, en nuevo juego etimológico) inició su liberación pese a las sucesivas añagazas tendidas por los hispanos.

En Waerschouwinghe aen alle goede inghesetenen van den Nederlanden, die tot beschermenisse van de vrijheydt van hunne religie, persoonen, previlegien, ende oude hercomen, teghens die tyrannie van de Spaignaerden ende heuren aenhanck t'samen verbonden ende verrnicht sijn (Advertencia a todos los honrados habitantes de los Paises Bajos, unidos en la defensa de la libertad de su religión, personas, privilegios y antiguos usos contra la tiranía de los españoles y sus aliados), impreso en $1583^{124}$, aparecen también acusaciones a la corta de la duración de los tratados firmados por españoles en lo concerniente a libertad religiosa y se avisa nuevamente de los peligros que la paz implicaba de caer otra vez bajo la tiranía española. Como medio más seguro para mantener la unidad de las provincias rebeldes y garantizar la acción coordinada se rechazaba el establecimiento de una República al estilo suizo o veneciano para pasar a defender la presencia de una autoridad fuerte y común a todas las provincias al mismo tiempo. Como medio de soslayar el yugo hispano se propuso acudir al Emperador y a los príncipes del Imperio, ofreciendo al Archiduque Matías el gobierno de las provincias si desde el Imperio les garantizaba protección, pero ante la falta de seguridades por parte de los estamentos del Sacro Imperio, acabaron recurriendo al duque de Anjou a cambio de que emplease el poder del rey de Francia, su hermano y señor, en la defensa de las provincias.

Aquí observamos dos cosas, la creciente hostilidad hacia los españoles y su rey y que los Habsburgo no fueron, como Casa, el blanco de las iras de los neerlandeses. Por lo que he podido rastrear en las Flugblätter, ni siquiera durante la Guerra de los Treinta Años se equipara automáticamente a los Habsburgo austriacos con los hispanos, ni en el seno del Imperio ni en las Provincias Unidas, lo que puede ser interpretado como indicio de que la dignidad ostentada más importante que la dinastía a la que se pertenezca o las actitudes personales de al-

124 Kossmann, E.H. y Mellink, A.F. (eds.), op. cit., pp. 249-251. 
guien tan determinado por la orientación confesional como el Emperador Fernando II. La diferencia de actitud respecto a la expresada por el canciller sueco en una alocución a la Dieta sueca en 1660 es notable, ya que en ella se sostenía la tesis, elaborada antes de 1648 , de que la Casa de Austria era el verdadero enemigo de la Respublica Christiana, ya que sólo aspiraba a arrebatar la libertad en asuntos religiosos y políticos a los estamentos del Sacro Imperio y, una vez colocado todo el imperio alemán bajo su dominio absoluto, imponer sobre esta base y en toda Europa su hegemonia en forma de Monarquía Universal ${ }^{125}$.

Durante las negociaciones de paz celebradas en 1579 bajo auspicio imperial, en las que los intermediarios propusieron a Felipe II la reinstauración de los privilegios y libertades para recuperar la obediencia de sus súbditos rebeldes a cambio de la imposición de la religión católica, se editaron numerosos panfletos. Uno de ellos es el titulado Brief Discourse on the peace negotiations now taking place at Cologne ${ }^{126} y$ que comparte la actitud negativa frente a un posible acuerdo. En él se afirmaba que las Provincias Unidas habían intentado firmar con su príncipe una paz buena y segura, pero que la actitud del rey hispano había demostrado que no pretendía el fin de las hostilidades ni estaba dispuesto a apoyar la Pacificación de Gante o a hacer concesión alguna para alcanzar la paz, lo que nos indica que la desconfianza ante los presuntos deseos de paz de la Monarquía Hispana fue una constante durante todo el tiempo que duró el enfrentamiento ${ }^{127}$.

Los franceses de 1635 también consideraron que si no se había podido llegar a una paz firme y duradera no habría sido porque ellos no hubieran hecho todo lo posible para lograrlo. Se afirmaba que «los Nuncios de Su Santidad son fieles testigos de la disposición con que auemos siempre reciuido la plática de paz, y quan favorablemente emos acetado las proposiciones que nos han hecho", poniendo así al papado por testigo de su buena voluntad y justificar que sólo las cons-

125 Barudio, G., Das Zeitalter des Absolutismus und der Aufklärung, 1648-1779. Frankfurt am Main, 1981, p. 263.

126 Gelderen, M. van (ed.). The Dutch Revolt. Cambridge, 1993.

${ }_{127}$ No sólo los "rebeldes" publicaron panfletos acerca de las negociaciones de paz celebradas en Colonia. Grondelicke Onderricting aen de gemeene Ingestenen van Nederlandt. Van tgroot gemackt off ongemack..., G. Schetz, s.l., 1579, es una obra redactada por un autor pro hispano y que busca la paz desde el reconocimiento de la autoridad monárquica y el rechazo a toda rebelión contra el señor natural (Kn., 497). 
tantes provocaciones y amenazas hispanas les han llevado a tomar el camino de las armas ${ }^{128}$.

La aversión demostrada por la mayoría de los panfletos y opúsculos polémicos hacia Felipe II y sus descendientes y en mucha menor medida contra Carlos V, contrasta con la opinión que merece María, reina de Hungría, pese a que ésta reprimió con dureza la rebelión producida en Gante (1539-1540) como protesta por los pagos que la ciudad debía realizar para sufragar las guerras del emperador contra el monarca francés Francisco I. Esto es una prueba de que el odio de los neerlandeses no se enfocaba hacia la dinastía Habsburgo sin distinción. En $A$ Defence and True Declaration... se afirma que gracias a su intervención se alcanzó la Paz de Augsburgo en el Imperio y se señala que se opuso a la tiranía de la Inquisición, para acabar siendo acusada de herejía ante el Emperador. No obstante, no por ello cejó en su lucha para mantener a los súbditos de su hermano en el amor de su señor natural ${ }^{129}$.

El rechazo de los neerlandeses hacia Carlos $V$ no fue, como ya se ha apuntado, general, ya que, como Geyl afirma, pese a las diversas fricciones consecuencia de la necesidad de financiar las interminables guerras del Emperador o por las persecuciones religiosas, la persona de Carlos seguía siendo capaz de despertar los sentimientos de adhesión a la dinastía que se había convertido en tradicional en las provincias patrimoniales ${ }^{130}$.

Aunque forma su núcleo principal, la producción de panfletos antihispanos en las Provincias Unidas no se limitó a la Guerra de los Ochenta Años, sino que también la encontramos en la guerra de sucesión de Jülich-Cleves, reflejada en los panfletos Fremder handel, 1614, Albeeldinge ende cort vertooch vanden seltsamen Oorloch..., Niclaes van Geylekerck, Ámsterdam, 1615, Kurtze abbiltung und verthonung von dem wunderbahrlichen kreigh der bey diser zeitten in kanf.. (versión alemana del anterior, 1615), Der kram des Romischen Papst. Sein werk und furnemen., Antoine Lancel, Ámsterdam, 1615, así como los diferentes grabados debidos a Claes J. Visscher, todos datados en 1615: Das Testament des Friedens oder Anstands, so etwan vor 6 Jah-

128 Declaración del Rey de Francia..., f. 212v.

129 Gelderen, M. van (ed.), The Dutch Revolt, p. 22.

130 GEVL, P., The Revolt of the Netherlands (1555-1609). London, 1958, p. 60. 
ren in Niederland gemacht worden, Verthooninghe ende verclaringhe van den Cleefschen $S$. Joris y Abconterfeytung und Erklerung des Cleuischen Ritters $S$. Jorgens, versión alemana del anterior, menos detallado en la narración del enfrentamiento entre Mauricio de Orange como S. Jorge, y Ambrosio Spínola como el dragón. Otros panfletos relacionados con el mismo asunto son, entre otros, Afbeeldige ende korte verklaringe ... van Gulick/ Kleef/ etc (1615) ${ }^{131}$, Abbiltung und kurtze bedeutung von den jenigen was im vergangenen Jahre gepassirt ist..., $1615^{132}$ y Bataefsche Spieghel vertoonende den Vrede-Standt, van ' $t$ Vry-vereenicht Nederlant, Ámsterdam, 1615, en el que se retrata a los dos símbolos de las Provincias Unidas (llamadas en el texto «peerle van Euroop"), la doncella y el león, armados y flaqueados por las personificaciones de la Religión y de la Política. Estos símbolos se oponen a los que representan a la Monarquía Hispánica, que son los jesuitas, personificados por Ignacio de Loyola, los monjes buleros, la Injusticia, la Miseria... En el texto se critica la acción de los hispanos tanto en América como en Europa, y se considera que el conflicto de JülichCleves es un atentado contra la tregua, así como una nueva prueba de la intención de la Monarquía Católica de aumentar sus dominios, terminando con un alegato en pro de la defensa de la verdadera libertad de las Provincias Unidas. Un interesante rasgo es que en esta Flugblatt se denomina a los hispanos "Spaensche Castilianen", lo que nos hace pensar que, pese a las afirmaciones de Maltby en sentido contrario ${ }^{133}$, sí se llegaba a distinguir fuera de la Península lbérica entre los diferentes reinos que convivían en el territorio bajo el mismo monarca. Los comentarios favorables dirigidos a los naturales de Portugal y Aragón, no obstante, no parecen haber tenido un excesivo efecto sobre la imagen general de la Monarquía Hispánica, en tanto que ésta era sinónimo de Castilla.

En todos los panfletos de esos años aparece el enfrentamiento entre el Estatúder y Spínola desde la óptica calvinista, que presenta la entrada en lucha de ambos bandos como fruto de la división confesional y la equiparación del ejército hispano con el Anticristo, a lo que se suman los atributos presentes en otros panfletos, como son la cruel-

\footnotetext{
131 HARMS, W., (ed.), Die Sammlung der Herzog August Bibliothek in Wolfenbüttel..., t. !I, Munich, 1980, pp. 174-189.

132 PAAS, J. R., op. cit., vol. 1, p. 325.

133 Mal-tBY, W. S., op. cit., p. 91.
} 
dad, la hipocresía, etc. Los animales escogidos para representar a cada uno de los líderes militares nos informan claramente de la toma de partido de los diferentes autores de los panfletos; si el dragón representaba a los calvinistas en algún panfleto católico, en algunos de los panfletos antes reseñados es la encarnación de el Marqués de los Balbases y, por extensión, de la Monarquía Hispánica, lo que vuelve a darnos idea de la pervivencia de cierto tipo de símbolos en las fuentes aquí analizadas y a demostrarnos que el universo mental es el mismo en todos los bandos; son los sujetos los que cambian, pero no las imágenes. Éstas no pretendian convencer racionalmente al receptor de las mismas y hacerle cambiar de opinión, sino despertar cierto tipo de emociones en los sujetos que las contemplaban, personas que ya poseian una orientación en la misma dirección que la de la publicación, que buscaba radicalizar y polarizar aún más la situación, acentuar las diferencias entre los bandos enfrentados ${ }^{134}$.

Sin embargo, los sentimientos de animadversión desaparecieron tras el fin de las hostilidades, como se recoge en Eere zy God inde Hoogste Hemelen ende Vreede op der Aerden (Rombout van den Hoeye, Ámsterdam, 1648) ${ }^{135}$, donde se narra la ratificación del tratado de paz entre la Monarquía Hispana y las Provincias Unidas de 15 de mayo de 1648 y se recuerda la evolución interior de los Paises Bajos tras la ruptura de hostilidades y se celebra la paz, asi como la independencia de las Siete Provincias respecto del Imperio. La firma de la paz significo el inicio de una nueva etapa de las relaciones hispano-neerlandesas ${ }^{136}$ pero los límites de la República, una vez alejada la posibilidad de ampliar sus territorios europeos, seguía mostrando problemas para su definición.

Como para "España», existía el problema de la denominación correcta para las Siete Provincias. En el S. XVII todavía se tendía a incluir, pese al fracaso de la Unión, a la actual Bélgica en los nombres aplicados a las Siete Provincias, puesto que "Provincias Unidas", "Países Bajos" - la misma palabra "Bélgica" podían hacer referencia tanto a las pro-

34 Kastner, R., op. cit., p. 303

135 HaRms, W., (ed.), Die Sammiung der Herzog August Bibliothek in Wolfenbüttel..., t. II. p. 556-557.

${ }_{136}$ Para ver el cambio de actitud entre la Monarquía Católica y las Provincias Unidas ver la obra de HERRERo SÁNCHEZ, M., El acercamiento hispano-neerlandés (1648-1678). Madrid, 2000 . 
vincias rebeldes como a las diez meridionales; resulta difícil determinar si eso era por falta de definición de la «conciencia nacional» o porque no se perdía la esperanza de reunificar las Diecisiete Provincias.

El otro nombre más común "Holanda" es, al contrario, restrictivo, hace referencia a la provincia más rica y extensa, pero ignora a las demás; además esta metonimia se ve reforzada por la conversión de Batavia en un mito fundacional del nuevo territorio, pues también hace referencia sólo, en origen, a Holanda. Resulta muy sugerente la posibilidad de realizar un estudio comparativo de las visiones de ambos territorios y analizar su influencia en tiempos posteriores, pero escapa claramente a los límites de este trabajo.

Para terminar se comentará un panfleto que alcanzó gran difusión y que resulta un resumen de las principales quejas que se tenían en el Imperio y en las Provincias Unidas de los españoles. Se trata de dos grabados iguales, solamente diferenciados por el idioma (francés en uno, alemán en otro). Se titulan Emblesmes sus les actions perfections et meurs du seignor espagnol. Traduit de castillien, y Emblemata. Welche das Leben/ die Thaten/Sitten/ und wunderbare Verwandlung des Segnor Spangliols deutlich erklären/ zuvor in Castillanischer/ danach in Niderländischer und Französischer/ und jetzt in hochteutscher Sprach beschrieben." y ambos fueron concebidos en torno a $1575^{137}$. En ellos aparecen 16 escenas en las que se representan la forma de ser y actuar del Segnor Espagnol desde el punto de vista de los neerlandeses y a través de comparaciones (en las viñetas 2 a la 9) con animales según las características que se les atribuyen en las fábulas. Se contrapone la imagen de piedad y devoción del español en la Iglesia (señalada como hipócrita en el texto, no en la imagen) con su tiranía diabólica en la casa y la glotonería (como un lobo) en la mesa. Como un cerdo en la esfera intima (defecando), pero vanidoso y arrogante como un pavo en el exterior y corrompe a las mujeres con la astucia de un zorro. En la guerra es valiente como un león cuando se halla en una fortaleza pero huye como una liebre durante la lucha en campo abierto y es manso como una oveja cuando le han hecho prisionero. Además es avaricioso, soberbio, cruel (en el texto se hace referencia a la ejecución de los condes Egmont y Hoorn), tiránico y aunque hable de

137 Harms, W., (ed.), Die Sammlung der Herzog August Bibliothek in Wolfenbüttel..., t. II, Munich, 1980, pp. 72-75. 
paz, lo hace tras haber jurado al Papa que exterminará a los herejes. Seguirá tiranizando y aplastando a sus súbditos (en la viñeta 13 se hace referencia a la opresión que ejerce sobre las Indias, Aragón, Navarra y, por supuesto, las Provincias Unidas) hasta que sea vencido por un verdadero cristiano ${ }^{138}$. La popularidad de esta ilustración debió ser notable, ya que conoció numerosas reediciones, alguna de ellas en momentos especialmente candentes, como fue durante las negociaciones de la Tregua de los Doce Años, lo que vuelve a mostrarnos la oposición de ciertos sectores hacia la finalización, aunque fuese temporal, del conflicto.

Se ha pretendido aquí introducir una fuente que, desde mi punto de vista, ha sido poco empleada para conocer la visión de la Monarquía Hispana en suelo europeo, si bien el ya mencionado trabajo de Peer Schmidt remedia en gran medida esa carencia. Es cierto que este tipo de literatura no se caracteriza habitualmente por una excesiva precisión, principalmente la ilustrada, panfletos, al fin y al cabo, concebidos para ser más vistos que leídos, redactados en lenguas vernáculas y que, lejos de imbricarse claramente con las teorias políticas más potentes y modernas del momento, lo que hacen es someter la realidad a un grosero maniqueísmo. Como uno de los muchos instrumentos empleados por la propaganda confesional, las hojas ilustradas tuvieron una serie de funciones especificas dentro del proceso de comunicación. Su fuerza específica residía en su capacidad para transmitir de un modo muy resumido y claro, además de contribuir a trasmitir ideas y visiones que eran desarrolladas con mayor amplitud, bien oralmente o en otro tipo de obras, con textos más extensos. El único medio que superaba la brevedad y concisión de la hoja ilustrada era la medalla conmemorativa, pero, quizá precisamente por ello, nunca llegó a tener la importancia de las Flugblätter.

No obstante, su brevedad y simplicidad no invalida en modo alguno la utilidad de las Flugblätter para el estudio histórico, ya que presentan,

${ }_{138}$ En ambas versiones que la primera redacción fue en castellano, se hace para dar a entender que los mismos castellanos se habian dado cuenta de sus horribles caracteristicas, aigo nada descabellado si se tiene en cuenta que dos de los personajes más citados a la hora de realizar estudios sobre los origenes de la Leyenda Negra son Bartolomé de las Casas y su Breve descripción de la destrucción de las Indias y las Relaciones de Antonio Pérez. El mismo artificio de poner en boca de un natural del país atacado las críticas que se le hacen lo emplea Saavedra Fajardo al adscribir a un francés su análisis negativo de la politica de Richelieu en su contribución a la polémica de 1635. SAAVEDRA Fajardo, Respuesta al manifiesto de Francia. Madrid, 1635. 
cuando menos, dos campos que sería conveniente estudiar con mayor amplitud: por una parte el papel que juegan las «mentes pensantes» del momento en la elaboración de esa propaganda y, por otra, su papel como creadoras de unas imágenes de larga pervivencia temporal, precisamente por su simplicidad. Siempre hay que tener en cuenta, además, que la mayoría de los grabados, panfletos y opúsculos aquí reseñados acaban mostrando que su casi única vocación es la crítica a los Habsburgo hispanos, lo que dota de una cierta unicidad a todas las obras, ya se trate del manifiesto francés de 16350 de uno panfleto tan burdo como los "Emblesmes sus les actions perfections et meurs du seignor espagnol» La Casa de Austria aparece retratada, como hemos visto, desde diferentes puntos de vista, casi siempre negativos y con unos argumentos muy similares, más o menos razonados pero siempre muy semejantes entre sí. Así, la tiranía hispánica, la falta de libertad, el deseo de establecer una monarquía universal, la hipocresía religiosa y la crueldad de tercios conforman la estructura de la práctica totalidad de los ataques y, lo más notable, contribuyen a elaborar una imagen que se ha perpetuado a través de autores, históricos y literarios, como Schiller hasta nuestros días, resaltando por ser único en lengua alemana el intento de presentar una visión positiva de Felipe II, y por extensión de los españoles de la época, de Ludwig Pfandl ${ }^{139}$.

Las Flugblätter nos permiten también acercarnos a la visión que de la guerra, especialmente de la Guerra de los Treinta Años, se tenia en la época. Las hojąs volantes aquí analizadas nos acercan a una visión de los conflictos hispano-neerlandés y germánico como asuntos principalmente religiosos, lo que se contrapone a la realidad de lucha política o de defensa de las libertades contra el poderío de la Casa de Austria. Esta disparidad puede hacernos recapacitar sobre la fuerza de cierto tipo de imágenes a la hora de configurar una opinión y un estado de ánimo favorables a la guerra; la religión es, como otros mitos incorpóreos, abstractos, un poderoso agente de integración y permite que gentes de diferentes territorios y lenguas, como los suecos y los diferentes príncipes protestantes, se sientan parte de un mismo cuerpo en el momento de la lucha. Esto puede explicar el hecho de que en ningún momento se mencione a Francia al lado de Suecia en los panfletos laudatorios hacia Gustavo II Adolfo, pero no explica suficiente-

139 Pfanol, L., Philipo II. Munich, 1938. 
mente la razón por la que en las Flugblätter no se mencionan las pretendidas aspiraciones habsbúrgicas a la Monarquía Universal, razón por la que ésta no se ha comentado aquí, que resultaban una de las razones por las que más se atacaba a la Casa de Austria desde los tiempos de Carlos V. Esta ausencia de referencias resulta sorprendente, si bien no he dado con la posible razón de la falta de atención a ese aspecto de la acción de los Habsburgo.

Otra de las conclusiones que se pueden extraer de las fuentes aquí consultadas es la idea de una España diferente al resto de Europa, en teoría alejada de los parámetros del resto de territorios, y cuya historiografía reclama incluso desde el S. XIV ser diferente al resto de la Cristiandad por no haber sido nunca parte del Imperio carolingio y que en los años setenta de este siglo sigue produciendo una literatura histórica que afirma, haciendo referencia al hombre del Barroco, que «el español [...] elabora una personalísima visión del mundo y de sí mismo de profunda hondura que se manifiesta desbordante y apasionada en todos los campos del pensamiento y del arte, inconfundible entre el repertorio cultural europeo" ${ }^{140}$, dando forma una especificidad cultural única, más original que las demás, con unos rasgos más marcados, más claros, prefigurando ya al lema España es diferente.

Pero, no obstante, sigue sin resolver el problema de qué es España. Según los datos de las fuentes, resulta sugerente la posibilidad de que nos encontremos frente a un ejemplo de creación de nación desde la exclusión, esto es, España es todo lo que, estando dentro de la Península lbérica, no es otra cosa, de la misma manera que Indonesia se convirtió en nación a través de la exclusión a la que era sometida un pueblo innominado por los colonizadores respecto a los demás grupos que habitaban la misma zona del Sudeste asiático ${ }^{141}$.

El término España remite así a unos referentes negativos, que circulan la literatura europea desde el s. XVI hasta el s. XVIII, cambiando con el devenir del poderío de la Monarquia Católica pero en torno a unos ejes básicos que, prácticamente, son los que se achacarán desde

140 CEPEDA ADÁN, J., “Los españoles entre el ensueño y la realidad", El Siglo del Quijote (1580-1680). Aeligión, filosofía y ciencia. Historia de España Menéndez Pidal, t. XXVI, Madrid, 1988.

141 Anderson, B., Comunidades imaginadas. Reflexiones sobre el origen y la difusión del nacionalismo. Méjico, 1993, pp. 173 y ss. 
dentro de España a Castilla. Así, si España fue un hito negativo en la historia europea, Castilla, cuyos límites son en la Edad Moderna tan nebulosos como lo son los de España ${ }^{142}$, se convierte en el mito nocivo, el espejo en el que nadie quiere mirarse. Desde Europa, de Schiller a Montesquieu y aún después, se rechaza cada vez con mayor dureza los referentes culturales e ideológicos de la Monarquía Católica y, por tanto, de España, que queda reducida a un territorio de excesos y crueldades, de fanatismo e intransigencia y, por qué no, un anacronismo en un mundo que había empezado, desde Westfalia, a explicarse a sí mismo desde unos referentes totalmente diferentes ${ }^{143}$.

Otro de los interesantes rasgos del que nos informan las hojas aquí estudiadas es el respeto que traslucen en la mayor parte de los casos por las autoridades establecidas. Como se ha visto, los neerlandeses dudaron mucho antes de criticar abiertamente a Felipe II, y prefirieron dirigir las acusaciones contra Alba y los demás «malos ministros». Por otra parte resulta llamativo que no se suela contraponer la figura de Guillermo de Orange con la de Felipe II, aunque se critique a éste, parece estar claro en la mente de todos que su dignidad estaba por encima de la del Estatúder. De ahí que resulte más pertinente establecer una comparación entre Gustavo Adolfo II y el Rey Prudente, aunque no fueran contemporáneos. Ambos gozaban de las mismas atribuciones, pero no así el de Orange, que, pese a lo reverenciado, nunca llega a tener la autoridad real, como demuestra el hecho, comentado antes, de que nunca gozase de la potestad de otorgar títulos de nobleza.

A esto se suma el principio del rey que no puede errar o de koning die geen kwaad kan doen, vinculado también al cambio de retórica evidente en los panfletos neerlandeses, cuando se pasa del buen rey, mal aconsejado por sus ministros, a la doble imagen, de un Felipe II tan cruel como sus ministros y a sus sucesores en el trono hispano, a los que, pese a la desconfianza que se evidencia hacia ellos, no se les

142 Las provincias vascas, el reino de Galicia, etc., pertenecen en teoría a la Corona de Castilla pero reclaman, entonces y desde la historiografía actual, un tratamiento diferente, de distincion frente a los territorios efectivamente dominados, sin otra filiación a la que remitirse, como La Mancha y Andalucia entre otros, aunque todos comparten la carencia de un derecho territorial específico, que es, a fin de cuentas, lo que caracteriza a un territorio.

143 Fernández AlBALADEJO, P., «Entre la "gravedad" y la ureligión": Montesquieu y la "tutela" de la Monarquia Católica en el primer setecientos", en IñuRRITEGUI, J.M. y PoRTILLO, J.M. (eds.), Constitución de España. Origenes y destinos. Madrid, 1998, pp. 25-49. 
pierde nunca el respeto, con lo que se evidencia una vez más el respeto debido a las dignidades.

La identificación de los jesuitas con la Monarquía Hispánica remite a un hecho señalado por Günter Barudio ${ }^{144}$, que reconoce que el impulso contrarreformista de la Compañía de Jesús no se limitaba a extender el catolicismo, sino que tenía una aplicación territorial, buscando recuperar los bienes que habían pasado a luteranos y calvinistas y, además, jugando con el principio de cuius regio... Jesuitas y Monarquía Católica eran dos caras del expansionismo católico, que resultaba comprensiblemente una amenaza para luteranos y calvinistas, tanto dentro del Imperio como fuera de él.

Se puede corroborar parcialmente la afirmación de J. Pérez, el cual sostiene que, en las críticas realizadas contra la Monarquía Hispánica todos los temas se pueden reducir a uno solo: «el fanatismo religioso identificado con España y con su monarca, enemigo declarado del protestantismo y campeón de la Contrarreforma" ${ }^{145}$, pero resulta necesario matizarla. España significaba mucho más, era el territorio sin leyes, donde no se respetaba el derecho, donde reinaba la injusticia y poblada por unas gentes avariciosas y crueles, que pretendían imponer su dominio sobre toda la Cristiandad y levantar asi un "Imperio del Terror" o el Reino del Anticristo.

144 Barudio, G., Das Zeitalter des Absolutismus..., p. 267.

145 Pérez, J., op. cit., p. 19. 